\title{
Chapter 4 \\ Decreasing Income and Reproductive Problems of the Agricultural Population
}

\subsection{Introduction}

In the previous chapter, we reviewed Spanish agroecosystems' means of production, that is, one of its two social fund elements. We did so by analyzing the evolution of inputs used. In this chapter, we describe the evolution of the agricultural population, the second social fund. The agricultural population emits a work flow that is measurable in terms of energy. It also originates an integrated information flow that supports its own structure and functioning. This flow is generated by households, whose "reproduction" is not only of a biological nature: it also relies on economic costs that have varied over time. Consequently, the concept of agrarian metabolism we put forward here takes into account not only the number of individuals engaged in agricultural work and the time spent on it but also their families or households and the paid or unpaid work time that is required to sustain them. The maintenance of a constant flow of human energy needed to manage agroecosystems depends on the reproduction of these agricultural groups. Reproduction costs must be covered by income from the sale of agricultural production or from wages obtained from the sale of labor power.

This second fund element is often characterized by paid work. But paid work is not fully operational in the case of agrarian metabolism because not all work going into agriculture is marketed, i.e., paid. Reproductive work and family care associated with biological reproduction constitute unpaid reproductive jobs though they are essential to reproduce agricultural work flows. We do not dispose of adequate sources to make a full-scale estimate of the time budget of all these reproductive tasks nor of all the other gainful activities (paid work outside the sector) that became ever more widespread as agricultural activity became less profitable. Though such estimates have been carried out for local case studies and provide us with valuable information for organic agriculture contexts (Marco 2017; Villa 2017), they go beyond the scope of this research for now. Statistical sources do not include any category enabling to quantify the number of households dedicated to agricultural activity anyway. 
However, in the absence of a full-blown analysis of agricultural households, it is possible to estimate their reproduction costs, understood as the amount of goods and services necessary to maintain and reproduce the household measured in monetary terms.

It is interesting to examine for that matter whether Spanish agriculture was able to sustain its agricultural population during the twentieth century and what impact it had on other fund elements. To this end, this chapter attempts to quantify the monetary flow that farmers received in exchange for their marketed production and their work throughout the period under study. Our main hypothesis is that they perceived insufficient income to sustain and reproduce their household. They were driven to seek higher incomes by specializing in crops with the most profitable market outlets or by intensifying production. Thus, close links can be established between insufficient income and tendencies towards intensification and productive specialization. Insufficient income derived from the unequal distribution of income among farmers themselves. Small farmers were especially affected, and many eventually abandoned their activity. But the reasons for income inequality differed at the beginning and at the end of the period under study. During the first half of the century, unequal distribution of agricultural income (internal inequality) meant that a large share of farmers perceived insufficient income. During the second half of the century, however, the sector at large saw its income drop. This fall persisted over time and especially weighed on small farmers. Income decline resulted from the deterioration of terms of trade, giving rise to the transfer of income to other sectors of activity (external inequality). In this context, productive intensification and specialization became a common strategy for all farmers, regardless of their size.

The lack of data sources was a major problem when performing our analysis of the first 50 years of the twentieth century. For this reason, all the information available for this period has been brought together in the first section. We have attempted to estimate household income and expenditure and their impact on employment and farm structures. Nevertheless, we disposed of much more information on developments since the 1950s, when inequality became external and most farmers began to follow the intensification pattern. The following sections separately analyze income, household spending behavior, the extent of achieved expenditure coverage and impacts on employment and farm structures. The chapter ends with some general conclusions on the agricultural population fund element's evolution, its current situation, and its prospects.

\subsection{The Agricultural Population During the First Half of the Twentieth Century}

By the end of the nineteenth century, communal property and rights had been completely dismantled. Small plots of municipal land (called "Propios") distributed to day laborers and small landowners had been privatized during the 1855 General 
Disentailment. From then on, day laborers began to depend almost exclusively on earned wages and small farmers, whether owners, tenants or sharecroppers, depended on the sale of their products. The commodification of their economies, that began when the Liberal Agrarian Reform was introduced at the beginning of the nineteenth century, had been completed (for a review, see Acosta et al. 2009). In this context, wages and prices became the central explanatory factors of farmers and farmworker decisions.

As we saw in Chap. 2, during the first third of the twentieth century, Spanish agriculture grew slowly initially and more vigorously later. This had consequences on the agricultural population's size and composition as well as on their reproduction strategies. The sources available for estimating the agricultural population during these years differ from the sources available after the 1950s, although all estimates are based directly or indirectly on population censuses led and published by the National Institute of Statistics or prior agencies. For the study period before 1950, we used the professional classifications established in the censuses to compile the information in Table 4.1 that reflects the evolution of the active population throughout those years. At least two distinct periods can be distinguished: that of falling active agricultural population between 1900 and the 1930s; and the forties and fifties when the population recovered and even exceeded its 1900 size.

In 1900, the active agricultural population exceeded 4.5 million male and female individuals. Female workers tend to be underestimated by official statistics, not to mention domestic and care work that largely remains outside the market still today, unreflected in national accounting. Women accounted for only $17 \%$ of total workers, and 1900 was also the year in which the largest amount of women's work appeared in the sources. Research carried out at a local level during these years suggests a much greater weight of women in agricultural work (Marco 2017; Villa 2017). The figure, as we shall see later, was not the biggest in the series in absolute terms, but it did represent the highest percentage of the active population (60.4\%) and of the population generally (25\%). For a sector that could still be defined as organic agriculture, human labor was essential, given its major role in agricultural work processes.

Table 4.1 Active agricultural population (thousand) and its percentage over total active population and total population

\begin{tabular}{r|c|r|r|r|r|r|c}
\hline Year & Men & Women & $\begin{array}{c}\text { Active } \\
\text { agricultural pop }\end{array}$ & Total active pop & $\%$ & Total pop & $\%$ \\
\hline 1900 & 3782.6 & 775.7 & 4558.3 & 7547.0 & 60.4 & $18,830.6$ & 24.2 \\
\hline 1910 & 3861.1 & 359.4 & 4220.5 & 7581.5 & 55.7 & $20,360.3$ & 20.7 \\
\hline 1920 & 4232.8 & 322.8 & 4555.6 & 7962.4 & 57.2 & $22,012.6$ & 20.7 \\
\hline 1930 & 3777.3 & 263.4 & 4040.7 & 8772.5 & 46.1 & $24,026.5$ & 16.8 \\
\hline 1940 & 4518.9 & 262.1 & 4781.0 & 9360.9 & 51.1 & $26,386.8$ & 18.1 \\
\hline 1950 & 4827.6 & 409.5 & 5237.2 & 10.793 .1 & 48.5 & $28,172.2$ & 18.6 \\
\hline
\end{tabular}

Source Population census. INE 
Table 4.2 Evolution of cultivated land productivity (considering only primary crops and not including residues and labor) in biophysical and monetary terms

\begin{tabular}{r|r|r|r|r|r|r|r|r}
\hline Year & $\mathrm{tdm} / \mathrm{ha}$ & \multicolumn{1}{c|}{$\begin{array}{c}1900= \\
100\end{array}$} & Pts/ha & \multicolumn{1}{|c|}{$\begin{array}{c}1900= \\
100\end{array}$} & $\begin{array}{c}\mathrm{t} \\
\text { dm/active } \\
\text { pop. } \\
\text { member }\end{array}$ & $\begin{array}{r}1900= \\
100\end{array}$ & $\begin{array}{c}\text { Pts/active } \\
\text { pop. } \\
\text { member }\end{array}$ & \multicolumn{1}{c}{$1900=$} \\
100 & & & \\
\hline 1900 & 0.68 & 100 & 138 & 100 & 2.45 & 100 & 723.7 & 100 \\
\hline 1910 & 0.71 & 105 & 127 & 92 & 2.99 & 122 & 783.8 & 108 \\
\hline 1922 & 0.79 & 116 & 138 & 100 & 3.28 & 134 & 814.4 & 112 \\
\hline 1933 & 0.82 & 121 & 166 & 120 & 4.13 & 168 & 1173.3 & 162 \\
\hline
\end{tabular}

Source Compiled by the author. Monetary data was obtained from Simpson $(1997,58)$, based on 1910 pesetas. Only the main crops were included to get as close as possible to monetary values. Therefore, the rest of the cultivated lands' net primary productivity is not accounted for Pts $=$ pesetas; $\mathrm{dm}=$ dry matter

The period of evolution of the active agricultural population ${ }^{1}$ can be divided in turn into two sub-periods: a first period during which the numbers of the active population remained more or less stable and a second, starting in the 1920s, when the numbers began to fall sharply. Labor productivity increase, measured in monetary terms (see Table 4.2), explains the $7.4 \%$ reduction reflected in the 1910 figures. This evolution pattern should have persisted. However, the numbers of the active population had recovered by the early 1920s and its percentage with respect to the total active population had barely dropped to $57.2 \%$. We can, therefore, say that the size of the active population remained almost stable during the first twenty years of the century.

This behavior is consistent both with agriculture's growth rates and the technological changes implemented in those years. The agricultural sector grew significantly between 1900 and 1933, as shown both by the increase in production per hectare and per worker, as illustrated in Table 4.2. But between 1900 and 1922, productivity per hectare grew very little in physical terms and not at all in monetary terms; the increase in labor productivity was slightly higher for both measurements. In contrast, during the 1922-1933 period, land productivity grew in physical terms at a similar rate to that of previous decades, but labor productivity accelerated, as the number of workers dropped sharply. In 1930 the countryside had lost more than half a million of its active population compared to 1900 . These active members of the population already represented less than half of the total active population and less than $17 \%$ of the Spanish population.

Productivity increases were due to Spanish agriculture's incipient processes of intensification and production specialization, as described in previous chapters. From a labor demand perspective, the dissemination of new irrigation technologies (Calatayud and Martínez Carrión 1999) and the use of chemical fertilizers (see Chap. 3) played an essential role. Increases in productivity per hectare could have

\footnotetext{
${ }^{1}$ The agricultural population is the population aged between 12 and 65 who can work in agriculture.
} 
been even greater had the cultivated land not grown by $23.7 \%$, thanks, among other things, to chemical fertilizers and new plows that carried out heavier-duty work. Increases in labor productivity rates were influenced, in turn, by the spread of new mechanical technologies. These technologies became more widespread during the twenties and were used more intensely, precisely as the active agricultural population began to decrease. Most technologies at the time were designed to save land and not labor force. Even as mechanization gained ground, it concerned traditional crops that required less labor than intensive crops, which are much more difficult to mechanize.

Similar developments were taking place in the rest of Europe, although the number of farm workers had begun to fall more rapidly. This relative divergence is due to multiple factors, but two issues proper to the case of Spain are worthy of mention: on the one hand, the structural nature of the differences in productivity, hard to overcome, and the new mechanical technology problems of adapting to Spanish agriculture's land and climate conditions. The fact is, despite agricultural growth, work processes continued to demand large numbers of workers on a punctual basis to realize concrete tasks: for example, the weeding and harvesting of cereals or the harvesting of olives. Olive grove harvesting would scarcely change until the 1980s (Infante-Amate 2011). Self-propelled machinery began to spread as early as the fifties. Until then, a relatively narrow relationship existed between each country's land and climate conditions and the possibilities of replacing human work with animal labor, leading to greater work productivity. Spain, with low net primary productivity, could not reach the same productivity levels per hectare or per worker achieved by other more northern European countries (González de Molina 2001). Productivity was conditioned by the employment offer that Spanish cereal rainfed lands could generate. These lands covered extensive stretches of territory and presented few alternatives of use. The employment offer was highly seasonal for crop and occasional in the case of fallows. This capacity was in stark contrast with that, for example, offered by irrigation, for which work demand existed almost throughout the year. It has been argued that the active agricultural population was in fact so abundant it discouraged the adoption of major measures of productivity improvement. However, this view, so widespread in Spanish economic historiography (Simpson 1997), obliviates that in reality there was very little that could be done to converge with other humid European countries.

Thus, during those years, agriculture relied on large numbers of individuals gathering in the fields to accomplish major tasks; these farm workers already relied exclusively on wages or received prices to survive. Wages were usually low and irregular. Agricultural unemployment did not consist in a percentage of workers without access to work, but in the number of days per year when there were no employment needs, unlike industry or services unemployment. This may explain why the different sector's administrations did not offer concrete data on agricultural unemployment during the first third of the twentieth century, unlike after the 1950s. Furthermore, the Spanish industry offered a limited amount of opportunities for alternative employment (Gallego 2001, 1986). Nevertheless, these general trends hide great territorial disparities: the number of primary sector employees dropped mainly in industrial 
areas, while in inland agricultural areas, these majority percentages remained largely unchanged. Precisely for this reason, unbalanced property distribution led to notorious peasant revolts giving rise to the so-called "agrarian question" (Acosta et al. 2009). We will return to this issue later.

Having described the size of the active agricultural population, we must now turn towards their income and expenditure requirements. Income is usually reflected in agricultural sector accounts and national accounts. These accounts are provided both by the Ministry of Agriculture and the National Institute of Statistics. However, the sector's accounts only began to be drawn up in the fifties, so we do not dispose of accounting information for the first half of the century. Reconstructing macromagnitudes over those years goes beyond the scope of this book. However, we do have some estimates on the value of total agricultural production (GEHR 1983) and final production (Simpson 1997) for the period before the civil war.

We also dispose of two estimates of the share of agriculture, fisheries and forestry in Gross Value Added (GVA): one carried out by Maluquer (2016) and another by Prados de la Escosura (2017). Although both estimations are based on the same final agricultural production size series provided by Prados, itself based on Simpson's final production calculations, we can find considerable differences between them. These differences are due to the various ways in which both authors related historical estimates with national accounting. Neither of them offers a series that is comparable with that offered by the sector's macromagnitudes, much less with an agricultural income series. In any case, we used both series as a proxy for the monetary remuneration that farmers would have received in exchange for their products. These series were calculated per farm worker, using our own employment series for the sector.

Although considerable differences can be observed between both series, both share a similar evolution that is generally consistent with that typically accepted by historiography. According to Prados, agricultural GVA per member of active agricultural population grew between 1900 and 1935 by $95.7 \%$, and by $55.8 \%$ according to Maluquer. It dropped between 1935 and 1950 by $35.4 \%$ and $1.9 \%$, respectively. Either way, there was an upward trend during the first third of the twentieth century in both series. Total GVA growth rates between 1900 and 1935 are similar in both series to those of GVA per member of active agricultural population (89.4\% for Prados and $50.7 \%$ for Maluquer).

Also worthy of interest is its relationship with the rest of the economy. Graphs 4.1 and 4.2 show the evolution of GVA per worker in agriculture and in the economy as a whole throughout the first third of the twentieth century. Although agricultural productivity was between 40 and $50 \%$ lower than that of the economy as a whole, this ratio did not decrease significantly in the first third of the twentieth century and that is the most relevant point. It is much more difficult to know to what extent the agricultural sector's productivity improvements were able to meet the needs of the agricultural population. We do not dispose of a series on disposable income or a series on basic rural household consumption. To solve this problem, we made some calculations the result of which should be considered as merely indicative. The first household budget survey to be conducted provides data on household consumption 


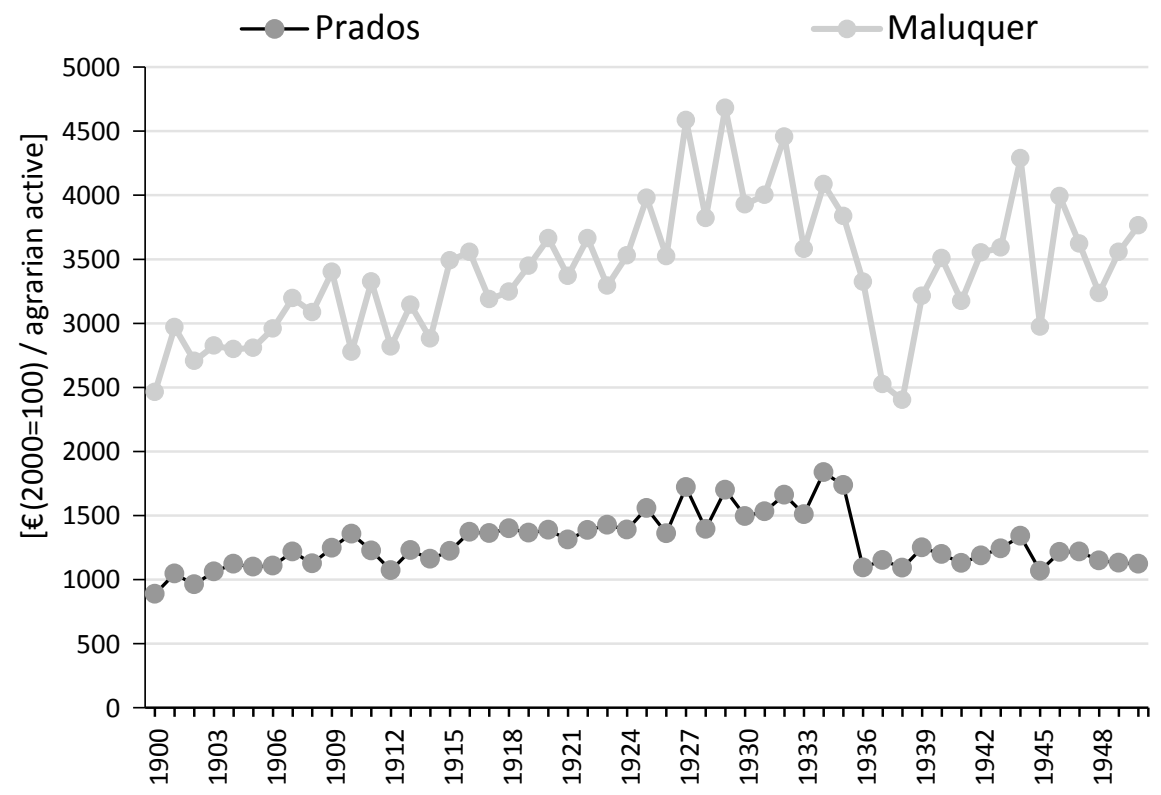

Graph 4.1 Gross value-added per active population member, in constant year 2000 euros. Source Maluquer 2016; Prados (2017) and our own active population data

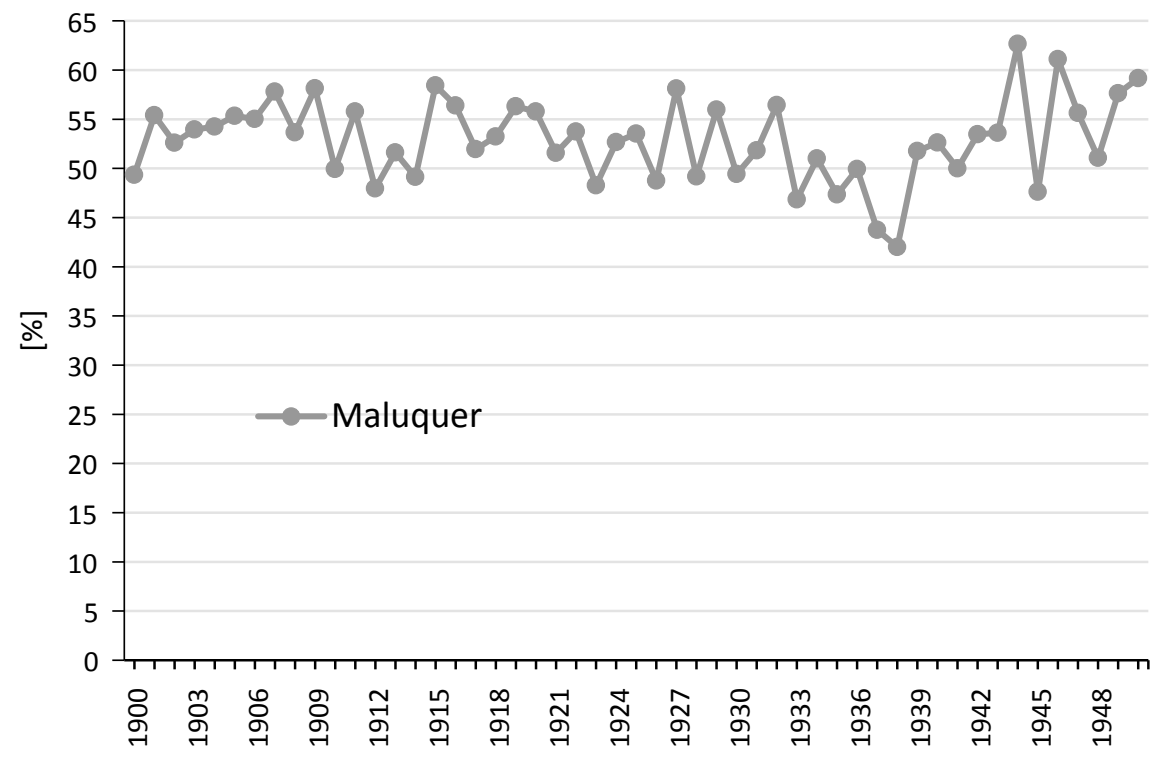

Graph 4.2 Share of GVA/member of active agricultural population compared to GVA/member of total active population. Source Maluquer 2016 and our own active population data (Given that the original series used by Prados and Maluquer is the same, the percentage ratio between agricultural and total GVA is identical. That's why we showed only one of the two series.) 
in 1958, including households living in rural areas, described as "suburban" in the surveys. According to our own reconstruction of the Spanish economy's metabolic profile (Infante-Amate et al. 2015), exosomatic consumption levels were similar to those in the first half of the century and endosomatic consumption levels were recovering those prior to the civil war (González de Molina et al. 2014, 2017). However, there must have been differences between 1900 and 1958. To uncover these differences, we assumed that household budgets followed a similar trend to that of national private consumption, estimated by Prados (2003, 405-410; and Carreras and Tafunell 2005, 1284-1285). We, therefore, estimated household budgets since 1900 based on 1958 household consumption, applying the same variation rate as that of private consumption from 1901 to 1950.

Table 4.3 compares the GVA per active agricultural population member of both estimates with average household expenditure over the 1900 to 1950 period in current pesetas, which gives an idea of the extent of coverage provided by agricultural income. ${ }^{2}$ Table 4.3 presents the data for three different periods: 1901-1905, 1931-1935, and 1946-1950. Discrepancies between Prados and Maluquer estimations can be observed, the latter indicating a wider coverage. In any case, at the beginning of the twentieth century, GVA per active agricultural population member covered $79.5 \%$ of household budgets according to Prados, while GVA was sufficient based on Maluquer's values, and there was even some remaining income. The relationship worsened in the thirties in both GVA estimates. At the end of the 1940s, the situation improved slightly according to Prados and clearly improved according to Maluquer. Real GVA values are probably situated between both estimates, therefore, close to the country's average household expenditure. Nevertheless, both estimates reveal a similar trend: a declining percentage of coverage throughout the first third of the century that is consistent with the progress of the country's economy. Despite agricultural production growth and the falling numbers of workers, household spending grew more rapidly and this reduced the extent of coverage of agricultural income. The evolution of apparent food consumption described in previous work corroborates this increase in household expenditure (González de Molina et al. 2014). The forties

Table 4.3 Comparison between estimated household budget and GVA per worker (current pesetas)

\begin{tabular}{r|r|r|r|r|r}
\hline & \multicolumn{1}{|c|}{$\begin{array}{l}\text { Household } \\
\text { budget }\end{array}$} & \multicolumn{1}{c|}{$\begin{array}{l}\text { GVA/Active } \\
\text { pop member }\end{array}$} & $\begin{array}{l}\text { GVA/Active } \\
\text { pop member }\end{array}$ & \% coverage & $\%$ coverage \\
\cline { 3 - 6 } & & \multicolumn{1}{c|}{ Prados } & Maluquer & Prados & Maluquer \\
\hline $1901-05$ & 2881.6 & 765.4 & 1114.8 & 79.5 & 115.8 \\
\hline $1931-35$ & $10,250.2$ & 1913.5 & 2745.4 & 66.4 & 95.3 \\
\hline $1946-50$ & 7104.9 & $11,314.5$ & 69.3 & 110.4 \\
\hline
\end{tabular}

Source 1958 survey of household budgets, Maluquer (2016), Prados (2003, 2017) and our active population data

\footnotetext{
${ }^{2}$ This calculation is merely an approximation given that GVA is not equivalent to income, but it provides a useful comparison framework.
} 
would represent a decline in the agricultural sector's GVA in constant pesetas, both for Prados and for Maluquer.

Strategies adopted by agricultural households must have been conditioned by income from agricultural activity in the absence of other production alternatives, as we have seen. In that sense, we have already emphasized the major role of inequality to explain intensification and specialization processes of Spanish agroecosystems during the entire study period, as inequality was the driver of a range of farmer strategies. Inequality was of course not the only reason. Agricultural income was indeed unevenly distributed and this encouraged the adoption of distinct production strategies that converged in the specialization and intensification of production. The analysis of property and farm structures should allow us to discover whether the land was distributed fairly among farmers, though it is only possible to perform this analysis starting from the first agricultural census to be published in 1962. The only information we dispose of is that published by Pascual Carrion, who gathered the results of the preliminary land register (Avance Catastral) until 31 December 1930 (Carrión 1932 [1975]). This information describes the structure of property and not that of farms. In addition, the data provided refer to 27 provinces, i.e., $62.4 \%$ of the total area. More northern provinces of the Peninsula are missing, generating a data bias favorable to larger farms and an underestimation of small farms.

Table 4.4 shows the taxable income declared by owners included in the Rural Land Cadastre (Catastro de Rústica), based on plot sizes. Obviously, the table does not fully capture the real number of owners as it is based on all registered landowners omitting possible redundancies in different areas and municipalities. Table 4.5 shows the approximate number of owners calculated by Carrión. Consequently, it classifies

Table 4.4 Distribution of registered wealth (taxable income) of farms (plots) in 1930

\begin{tabular}{l|r|r|r|r|r}
\hline & \multicolumn{1}{c|}{ Pesetas } & \multicolumn{1}{c|}{$\%$} & \multicolumn{1}{c}{ Owners } & \multicolumn{1}{c}{$\%$} & \multicolumn{1}{c}{ Pts/owner } \\
\hline Up to 10 ha & $361,221,300$ & 51.66 & $10,016,115$ & 98.06 & 36.1 \\
\hline From 10 to 100 ha & $134,484,324$ & 19.24 & 169,472 & 1.66 & 793.5 \\
\hline From 100 to 250 ha & $58,757,117$ & 8.40 & 16,305 & 0.16 & $3,603.6$ \\
\hline More than 250 ha & $144,857,076$ & 20.71 & 12,467 & 0.12 & $11,619.2$ \\
\hline Total taxable income & $699,118,386$ & 100.00 & $10,214,359$ & 100.00 & 68.4 \\
\hline
\end{tabular}

Source Pascual Carrión (1932 [1975], 100-101)

Table 4.5 Distribution of agricultural wealth among owners in 1930

\begin{tabular}{l|c|c|r|r|r}
\hline & Pesetas & \multicolumn{1}{c}{$\%$} & \multicolumn{1}{c}{ Owners } & \multicolumn{1}{c}{$\%$} & Pts/owner \\
\hline Small owners [>1000 pts] & $228,431,436$ & 32.68 & $1,699,585$ & 94.94 & 134.4 \\
\hline Medium owners [1000-5000 pts] & $176,711,520$ & 25.28 & 73.092 & 4.09 & $2,417.7$ \\
\hline Large owners[+5000 pts] & $294,028,428$ & 42.06 & 17.349 & 0.97 & $16,947.9$ \\
\hline Total & $699,118,386$ & 100.0 & $1,790,026$ & 100.0 & 390.6 \\
\hline
\end{tabular}

Source Pascual Carrión (1932 [1975], 112-113) 
the cadastral plots according to their owners. As mentioned, the table does not reflect the real number of leasing and sharecropping cases, so there must have been a smaller number of large farms and a higher number of small and medium farms.

A total of $98.06 \%$ of owners had plots under 10 hectares that generated barely more than half the taxable income. Average income per plot and owner was just over 36 pesetas, not including labor costs that counted as income for most farmers. Either way, we can assume that many small plots were grouped into larger farms via leases or other transfer agreements, given that $77.67 \%$ of them were below one hectare and $96 \%$ below five hectares.

Nevertheless, Carrión's data gives an idea of land access inequality and the unequal distribution of agricultural activity income. The data also confirms the overwhelming weight of small properties and dependence on work on self-owned farms or work for others. We can logically assume that the vast majority of these small landowners sought to maximize agricultural income either by specializing their production in more easily marketable crops or by intensifying the production of subsistence crops. Based on the data in Table 4.3, they succeeded. Both strategies have been observed among small farmers in the region of the Vega de Granada. At the turn of the century, they adopted beet crops and were the first to use chemical fertilizers (González de Molina and Guzmán Casado 2006); they have also been observed among a large part of small farmers, who turned to cultivating olive groves in Andalusia and managed them more intensively (Infante-Amate 2014).

For their part, employees, threatened by seasonal unemployment and the lack of alternative employment outside the sector, developed strategies to strengthen their role in the labor market. They found ways to receive better salaries and working conditions by constituting local unions at first, and later, by becoming members of national unions ( $C N T$ and $U G T)$, or even political parties such as the PSOE and some republican groups. This resulted in notable increases in peasant protests that became especially intense during the so-called Bolshevik Triennium (1918-1920). Since then, an increasing number of agricultural conflicts were resolved through collective bargaining accompanied by wage increases. Interested readers may find a detailed description of this process in our research (Acosta et al. 2009) on the origins of the National Federation of Land Workers (Federación Nacional de Trabajadores de la Tierra). This pressure strategy and union mobilization of rural workers resulted in wage increases (Graph 4.3).

The specialization and intensification strategy came to be shared by farmers who depended on external labor. During the crisis at the end of the century, when agricultural prices were low, wages were relatively low and there were structural shortages of fertilizers (most of them were still organic), the most logical strategy was to replace soil fertility within the farm, without using external fertilizers. This meant extensifying production, while reducing labor and fertilization costs. This extensification strategy explains the rise in unemployment during those years and the early twentieth century's fierce social crisis (Acosta et al. 2009). The doctoral thesis by Inmaculada Villa (2017) regarding Montefrío (Granada), an inland Andalusian town, shows that this strategy was followed by medium and large landowners. Protests for more work and better wages were repressed by authorities almost throughout Spain: 


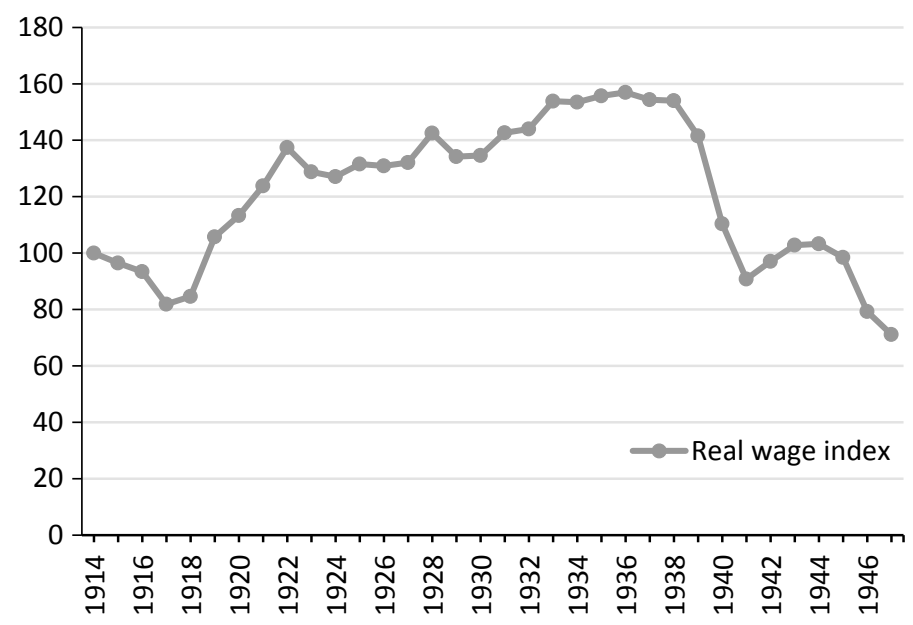

Graph 4.3 Index of real average wages of agricultural workers (men) $1900=100$. Source Carreras and Tafunell (2005). Deflated by the CPI prepared by Maluquer (2013)

repression by the Spanish military police (Guardia Civil), by the army, strike bans, restrictions of association rights, etc. Things would change during the First World War. As described just above, wages rose to compensate for the increase in living expenses and working conditions improved thanks to rural workers' protests. The rise in wages should have led to a change in the strategy by farmers hiring wage labor. The most logical outcome would have been the substitution of labor by machines, given the bigger weight of labor costs on income. Meanwhile, the use of chemical fertilizers intensified. Intensification by increasing the yields per unit area, mainly possible thanks to chemical fertilizers, became an achievable means to compensate for the rise in labor costs. Although we cannot expect a direct correlation between wage increases and the use of mineral fertilizers, both variables visibly followed a similar trend during those years. In this way, practically all farmers gradually adopted intensification and specialization strategies.

Franco's dictatorship led to a "disorderly turnaround" back to organic agriculture, that was unbalanced, notoriously inefficient and now lacking agrosilvopastoral integration. Agricultural production dropped to levels recorded at the beginning of the century. In a context of nutrient deficits and scant machine use, the number of agricultural workers rose to unprecedented levels. As illustrated in Table 4.1, the 1940 active agricultural population exceeded that of 1900, accounting for over half the workers in a country that went back to being mainly agricultural. The number of workers reached its peak in 1950 with more than 5.2 million, i.e., $48.5 \%$ of total workers. The active agricultural population was still above that of 1900 at the start of the sixties, with 4.6 million individuals, $91 \%$ of whom were men. As we saw in Chap. 2, the Civil War led to considerable damage to the work animals and considerable efforts were necessary in the following years for its recovery. The lack of animal traction had to be compensated by greater use of human labor, subject to an 
almost punitive regime of labor relations and low wages (Naredo and Sumpsi 1984). Agricultural worker income followed the same trend, almost reverting, as shown in Table 4.3, to values at the turn of the century. Extensification and the punitive labor regime did not allow for input-based intensification to take place.

\subsection{An Estimate of the Agricultural Sector's Macromagnitudes (1950-2008)}

To compile farmers' incomes since the 1950s, we dispose of the Sector's Accounts included in the National Accounts. Despite this, the task was challenging given the variations in information quality, included items and the distribution of economic sectors throughout the period. The main problem is the lack of a consistent series. We dispose of three large accounting models with notable variations. Between 1950 and 1989, agricultural macromagnitudes were published in accordance with the FAO's methodology, which integrates agriculture, livestock and forestry accounts. With Spain's incorporation into the EU, there were changes and the SEC 79 Eurostat methodologies were adopted to draw up national accounts. The Agrarian Statistics Yearbooks (Anuarios de Estadística Agraria) include the 1986-1996 series based on this methodology. The White Paper on Agriculture and Rural Development (Libro Blanco de la Agricultura y el Desarrollo Rural, MAPA 2003) published the retrospective series between 1974 and 2000 for the Agrarian Branch based on this methodology only. A final conceptual change occurred with the SEC 1995 methodology, still in use today that makes considerable changes to national accounting (Maluquer 2009a). As mentioned, the FAO series includes agricultural, livestock, and forestry production, while the latter methodology separates forestry accounts (also published only until 2003). But the changes are not only conceptual, since agricultural production and income values are greater based on the SEC 95 methodology than on the two previous methodologies for years where matching figures can be found.

To solve the problem, we chose to build a uniform series on agricultural production, intermediate consumption and income using the retropolation technique from the SEC 95 series up until the two former series. ${ }^{3}$ Given that the series is meant to provide approximate total monetary flows, we also included silvicultural production data. As information is lacking for this field since 2004, we assumed that the same percentage weight of the 1999-2003 average had been maintained in the 2004-2008 period. ${ }^{4}$ The series offers the results both in current prices and in real values. To deflate the production series, the farmers' price index (available since 1953 in the

\footnotetext{
${ }^{3}$ This technique takes into account that new accounts incorporate items not included in previous ones and, therefore, maintains older series trends by increasing the size. We are aware of the limitations, but it is the only possible solution given the current information we dispose of. The problems and advantages of different linking alternatives are discussed in Maluquer (2009a, b) and Prados de la Escosura (2009).

${ }^{4}$ The forestry sector's contribution is not very significant anyway: $2.4 \%$ of production, $0.8 \%$ of Intermediate Consumption and $3.6 \%$ of income.
} 
Agricultural Statistics Yearbooks) was used. The index of prices paid by farmers (available from the same source since 1957) was used for the intermediate consumption series and the Consumer Price Index (CPI) (found in Maluquer 2013) was used for agricultural income. Costs of hired labor were deducted from agricultural income to obtain farmers' income, which we consider a proxy of Farm Family Income. Thus, farmers' income enables us to analyze the evolution of their purchasing power. We will compare this latter purchasing power with the evolution of household expenditure in the following section. However, agricultural income is not necessarily the only type of income perceived by agricultural households. It is well known that over the last decades, unemployment insurance, pensions, and other public transfers have represented a significant source of income, added to income from other gainful activities. Either way, we assumed that the amount of income derived from agricultural activity largely explained farmers' production decisions.

Agriculture's confirmed loss of relative weight in the economy is not the end of the story. Over the last decades, the exchange ratio between agriculture and the rest of the economy has steadily declined, partly explaining agriculture's falling relative weight. This weight decline has led to a lopsided relationship that affects agriculture's economic viability and is one explanatory factor of its industrialization process. The best demonstration of this is the relationship between price indices. Graph 4.4 shows the evolution of the ratio between the prices received by farmers and the CPI on the one hand and between the prices received by farmers and the prices paid on the other. The figures show a regular decline in the received price/CPI ratio throughout the study period, with significant repercussions, as we will see later, on the evolution of farm income. Certain events had particularly strong impacts. For example, in the years after the Moncloa Pacts (1977), the decline accelerated. On the other hand,

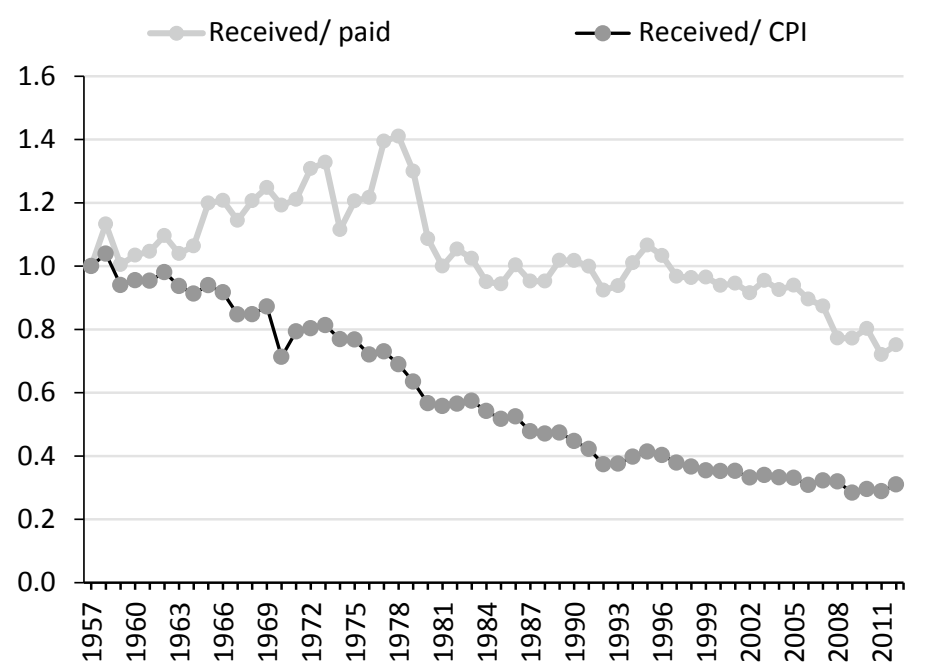

Graph 4.4 Relationship between price indices, "received", "paid" and "Consumer Price Index (CPI)". Source Agricultural Statistics Yearbooks and Maluquer 2013 
terms of trade ceased to deteriorate between 1980 and 1983 and from 2007 onwards due to the effects of the crisis. The evolution of the ratio between prices received and prices paid was much more affected by the evolution of some basic products prices such as oil, but two distinct periods can be distinguished. The first period, between 1957 and 1978, shows a favorable trend for farmers, somewhat tinged by the oil crisis. This fact is striking since it coincides precisely with the acceleration period of agriculture's industrialization. However, as from the so-called Moncloa Pacts (1977) between the Government, employers' associations and trade unions, the trend reversed and the terms of trade between agricultural products and input prices became negative. The decline accelerated from the mid-nineties, especially since 2007 and constitutes a major mechanism of transfer of agricultural income to other economic sectors, accentuated by the increase in absolute terms of input use (Graph 4.6).

Main agricultural production trends, both in monetary and physical values, have been described in Chap. 2. Graph 4.5 summarizes Agricultural Production trends both in current values and in real terms. In both cases, growth has been notable, with annual cumulative growth rates of $8.4 \%$ in current values and $2.8 \%$ in constant values. Either way, we can confirm that production stagnated in our century. In Chap. 2 we showed how a large share of this growth was explained by the concentration of production in marketable biomass and not by the limited growth of net primary productivity per hectare.

Agricultural production growth was accompanied by ever greater reliance on external inputs, as seen in Chap. 3. Agriculture's intermediate consumption grew much more intensely (Graph 4.6), with annual cumulative growth rates of $10.8 \%$ in current values and $4.7 \%$ in constant values. But several phases can be clearly distinguished even during the period of almost constant growth until the beginning of the century: a first phase of intense growth, coinciding with agriculture's industri-

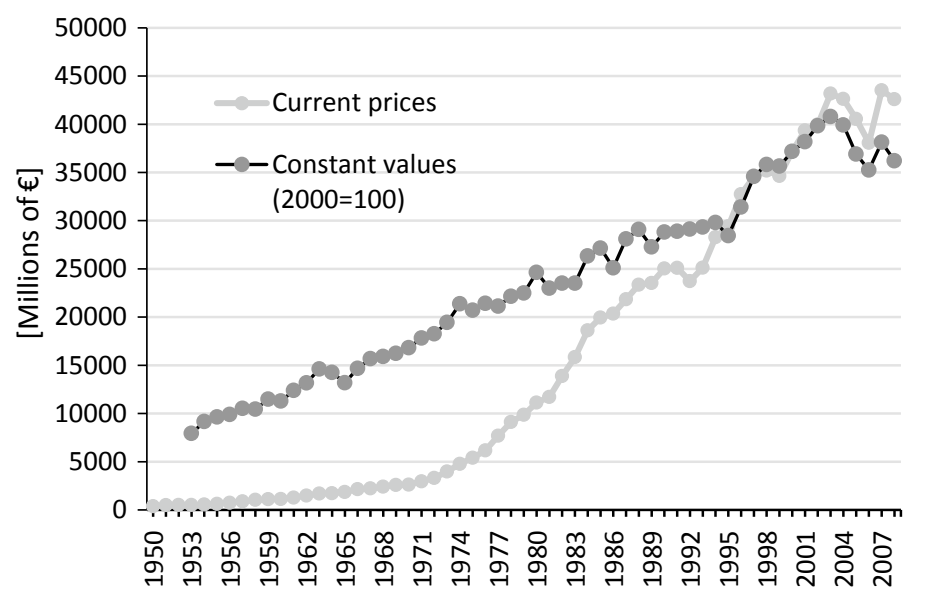

Graph 4.5 Agricultural production. Source Agricultural Statistics Yearbooks (see justification in the text) 

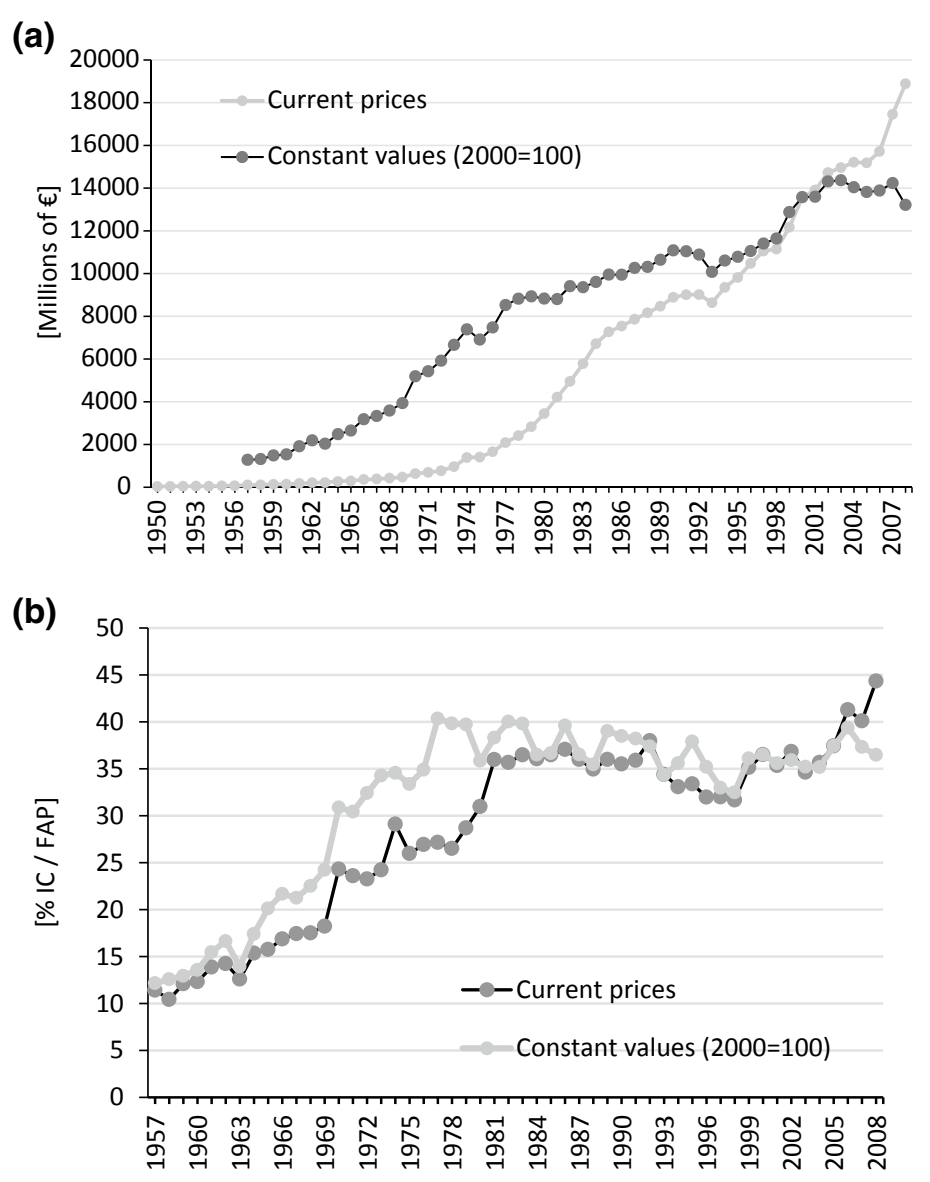

Graph 4.6 Evolution of intermediate consumption, millions of year 2000 euros (a) and in percentage of Final Agricultural Production (b) Source Agricultural Statistics Yearbooks (see justification in the text)

alization process, until 1978 (annual growth rate of 9.6\%); a phase of much more moderate growth until 1993 (0.89\% per annum) coinciding with Spain's accession process to the EU; and a short period of $4.4 \%$ annual growth from 1993 until the turn of the century. To finish, intermediate consumption began to drop in real terms since the year 2000 .

Despite recent drops in intermediate consumption, after 2010, price dynamics have prevented this trend from being beneficial for farmers. Farmers have been forced to continue to dedicate an increasing share of their agricultural production value to covering intermediate consumption, notably affecting their income. Graph 4.6 shows the production percentage represented by expenditure outside the sector in constant and current values. These two indicators express different meanings. The first indicator (when deflating the production series with the received prices and 
intermediate consumption with the prices paid) measures the variation in external input requirements per unit of output. In this sense, the evolution corresponds to the trend commented above. During the agricultural industrialization period, intermediate consumption reached $40 \%$ of production, and has remained close to that figure ever since. The percentage between intermediate consumption (hereon IC) and Final Agricultural Production (hereon FACP) in current values measures the production share that farmers dedicated to paying for intermediate consumption. This indicator is strongly dependent on price dynamics; it is much better suited to explain agricultural income dynamics and reveals a somewhat different evolution. Until 1981, the percentages were lower than in constant values (not exceeding 35\%), because of farmers' favorable price ratio as mentioned earlier, although from that date onwards it stabilizes, growing strongly at the turn of the century until reaching $44.3 \%$ in 2008. The sharp rise in prices paid in the first years of the twenty-first century has meant that farmers have had to allocate an increasing part of their production to satisfy inputs needs from outside the sector.

Intermediate consumption growth is traditionally considered as a positive indicator of agricultural activity's integration in global economic activity, or as an indicator of technification (MAPA 2003). Undoubtedly a second reading is, however, possible, such as the one adopted in this book. And it is rather less rosy. The use of inputs has increased IC costs, pushing agricultural farms to compensate for this growth with more production or greater production specialization in a vicious circle, relying ever more on markets. This explains why, despite the relative production extensification and recent abandonment of "marginal" lands as described above, biomass extracted for commercial purposes has increased in cultivated lands. Generally, intermediate expenditure growth has only reflected a significant rise in non-renewable energy inputs, as well as increasing prices and negative environmental impacts as highlighted in Chap. 3. Similarly, from an economic viewpoint, IC growth has contributed to making agricultural activity ever less viable, by notably affecting the dynamics of agricultural income and the deterioration of terms of trade between farmers and the economy as a whole.

These conditions can be observed in agricultural income dynamics, reflected in Graph 4.7, both in absolute terms as well as per active and employed individual. Agricultural income in current euros shows constant growth until the turn of the century. However, in absolute terms and in constant year 2000 euros, two periods can be distinguished. A first period of growth, from 1950 to 1963, largely reflects the recovery from the depression caused by the Civil War and autarchy, as observed in the economy as a whole (Maluquer 2016; Prados de la Escosura 2017). But as of that date, agricultural income declined heavily and steadily, by $43 \%$ over the whole study period. The decade between 1977 (the Moncloa Pacts) and the entry of Spain into the European Union was particularly significant: income fell by $31 \%$ in absolute terms. As previously observed, this period also corresponded to an acceleration in the deterioration of terms of trade. 
(a)

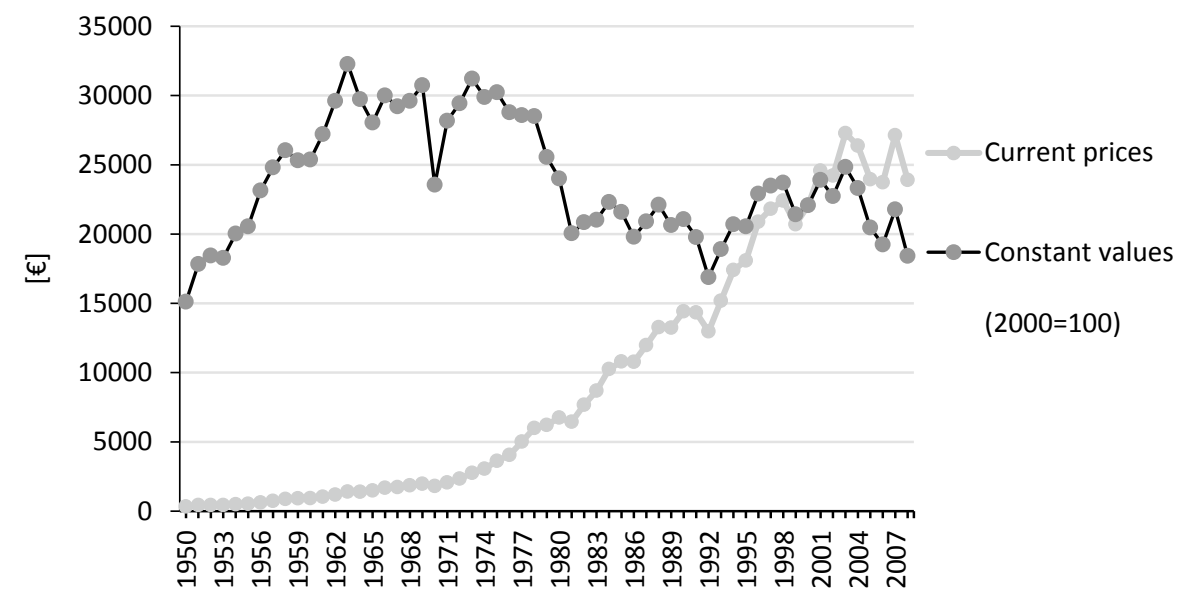

(b)

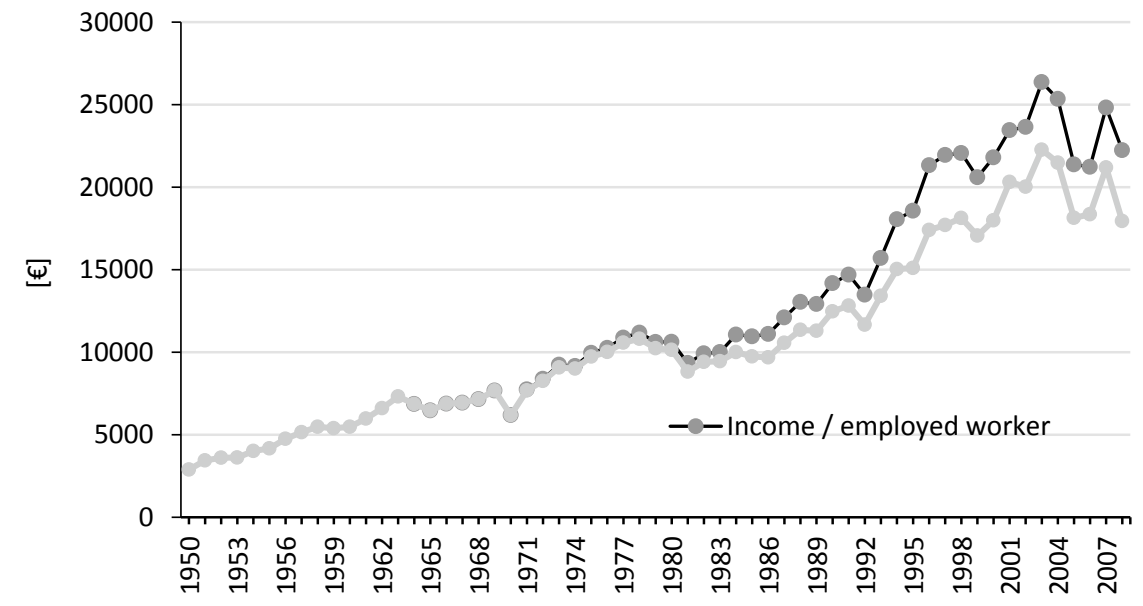

Graph 4.7 Income per active population member (a) and employed worker (b), in constant year 2000 euros. Source Agricultural Statistics Yearbooks (see justification in the text)

The drop has only been partly compensated by two other mechanisms. To start with, the fall was softened by the rising impact of operating subsidies that grew since Spain joined the EU to around $20 \%$ of the total income value (Graph 4.8). But the main compensation factor was the destruction of employment (partly linked, in turn, to the loss of farms) and the abandonment of agricultural activity that allowed not only to maintain income but to increase it per working population or employed worker until early this century. This increase, as indicated in the White Paper on Agriculture (MAPA 2003), has been above the EU average. Though the phenomenon could be read positively based on a strictly conventional analysis of the economy, it has led to negative consequences described earlier: land abandonment, rural depopulation, 


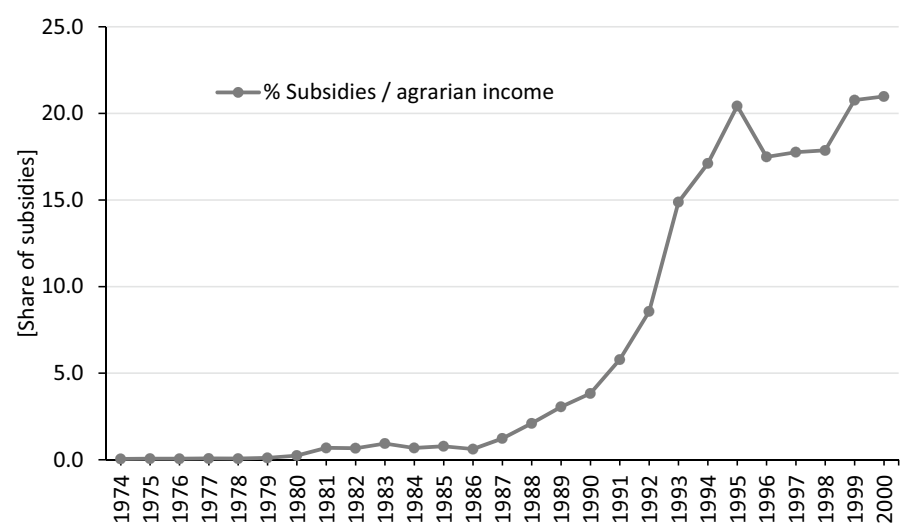

Graph 4.8 Share of subsidies in agricultural income. Source Agricultural Statistics Yearbooks (see justification in the text) and MAPA (2003) (It is impossible to build a consistent series of subsidies given the enormous changes in the accounting on the types and amount of included subsidies. We took (for indicative purposes) the longest uniform series of subsidies offered by the white paper on Spanish agriculture. (MAPA, 2003).

deagrarization, etc. Furthermore, in the context of the economic crisis, agriculture has done little to alleviate the effects of the unemployment crisis, as we will see in the following sections.

\subsection{The Agricultural Population and Changing Living Standards}

In this section, we examine the transformations in agricultural households' living standards. Agricultural households have shared, along with Spaniards and Europeans generally, considerable increases in living costs throughout the twentieth century, which have lasted to this day. As the metabolic profile of contemporary societies has increased, exosomatic consumption of energy and materials has become greater and its monetary cost has risen. Spain went from consuming 4.1 tons of materials per capita in 1950 to consuming 16.3 tons in the year 2000, a four-fold increase (Infante et al. 2015). Biomass represented $73 \%$ of materials in the fifties dropping to $19 \%$ in the year 2000. The growth rate has been slower than in central and western European countries, but in recent years a remarkable convergence has taken place, reaching an approximate EU-28 average of $15.6 \mathrm{t} / \mathrm{cap}$ in the year $2000 .^{5}$ This progressive increase in the reproduction costs of agricultural households is highly relevant to our research.

${ }^{5}$ Eurostat, consulted on 20 May 2018. 
We dispose of sufficient information for the sixties onwards on the evolution of living costs, included in the Household Budget Surveys (Encuestas de Presupuestos Familiares, EPF) conducted and published by Spain's National Institute of Statistics $(I N E)$. As widely known, the surveys began to be designed in the fifties, following an unsuccessful attempt at the start of the previous decade. The first survey was published in 1958. By studying and homogenizing the data, we were able to reconstruct the evolution of Spanish households' average expenditure, both nationwide and for urban and rural areas. The panorama is that indeed, household expenditure has been on the rise ever since. Spanish households' average expenditure grew throughout the whole period, except in the years 1973/74/80/81 and 1990/1991-1996, during which a slight drop can be observed due to economic crises in those years. Growth took place despite a steady decline in average household size, which went from just over 4.5 members in 1958 to 2.6 in 2008 (Graph 4.9).

As shown in Graph 4.10, average household expenditure increased almost fourfold between 1958 and 2008 in constant 2008 euros. The graph shows two periods: the first period is one of accelerated growth and transition to mass consumption, strongly linked to the recovery from terrible living conditions under Francoism, and a second period of slower spending growth from the seventies onwards. This trend was interrupted by the oil crisis and the early nineties economic crisis, as illustrated in the graph (Graph 4.10).

Spending increases were widespread both in urban and rural areas, although household spending in rural areas was always significantly lower than the national average, reflecting somewhat lower living standards (Graph 4.10). The difference between the countryside and the city was not very notable in 1958 but increased sharply in 1964/65 and continued to do so in the following decades. It began to converge again in the mid-nineties. Either way, spending differences between urban and rural areas were always notable: they reached a peak of 41\% in 1964-5 taking average national expenditure as a reference, and $9 \%$ in 2008, its lowest point (Graph 4.11).

Graph 4.9 Household composition, in number of household members. Source Compiled by the authors based on Household Budget Surveys of the National Institute of Statistics (INE)

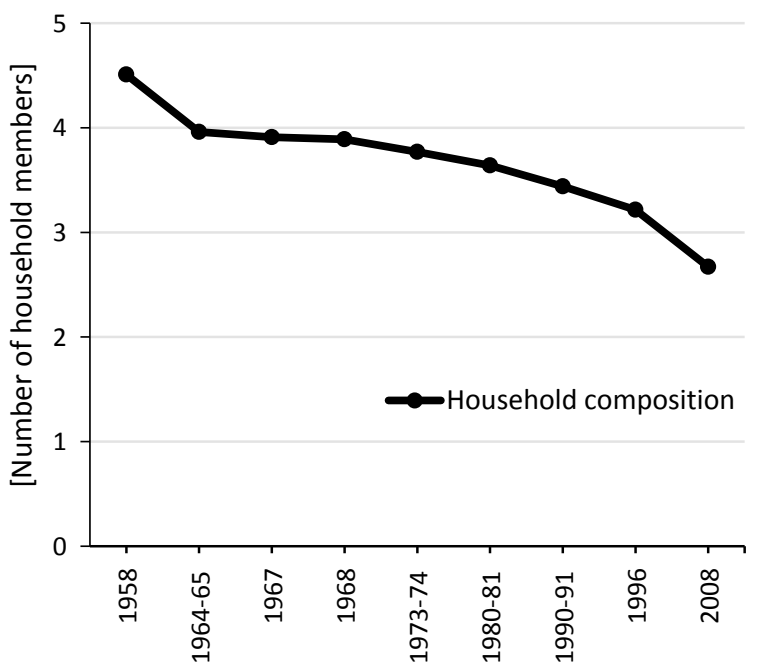


Graph 4.10 Evolution of average household expenditure according to territorial area, in thousands of the year 2008 euros. Source Compiled by the authors based on the household expenditure surveys of the National Institute of Statistics

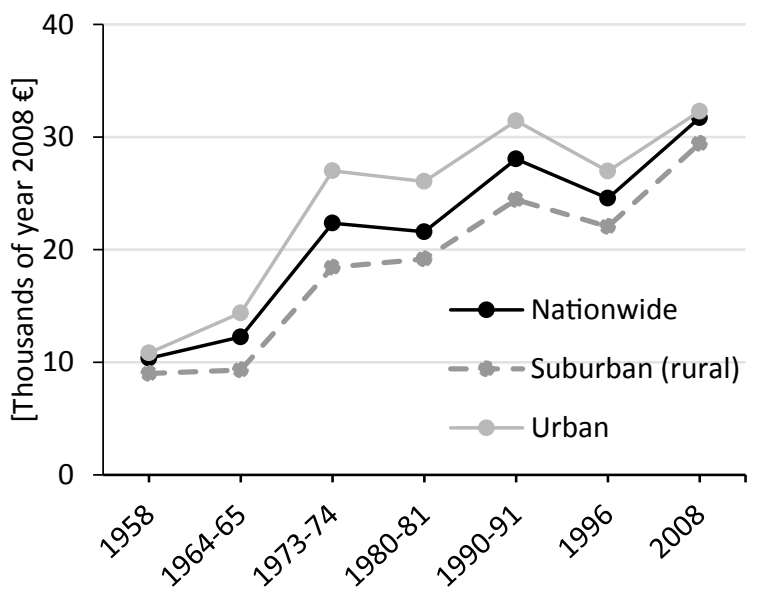

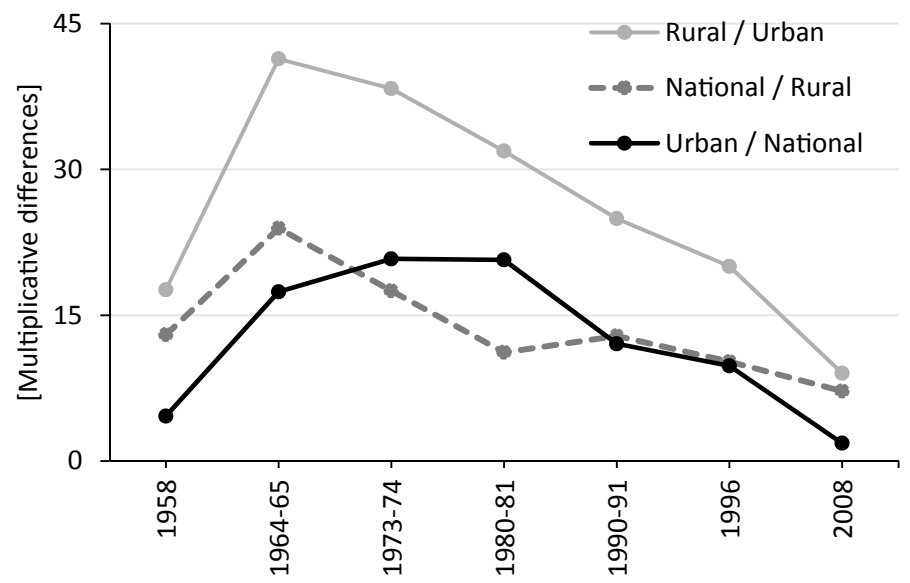

Graph 4.11 Differences in average urban, national and rural/suburban spending, in percentages. Source Compiled by the authors based on the household expenditure surveys of the National Institute of Statistics

Despite significant differences between the countryside and cities, the expenditure structure does not greatly differ. The categorization was not maintained over time in published Household Expenditure Surveys, as is the case for large amounts of statistical information. This obliged us to work on homogenizing the categories before comparing them. For the last years, the homogenization was conducted by aggregating categories. However, for 1958, the category "General Expenditure 1958" could not be broken down to make it comparable with the categories of the following years, so we decided not to modify it. Thus, this broad category is the sum of the categories "Other expenses", "Transport and communications", "Medical services and health conservation", and "Leisure, education and culture" (Graph 4.12). 


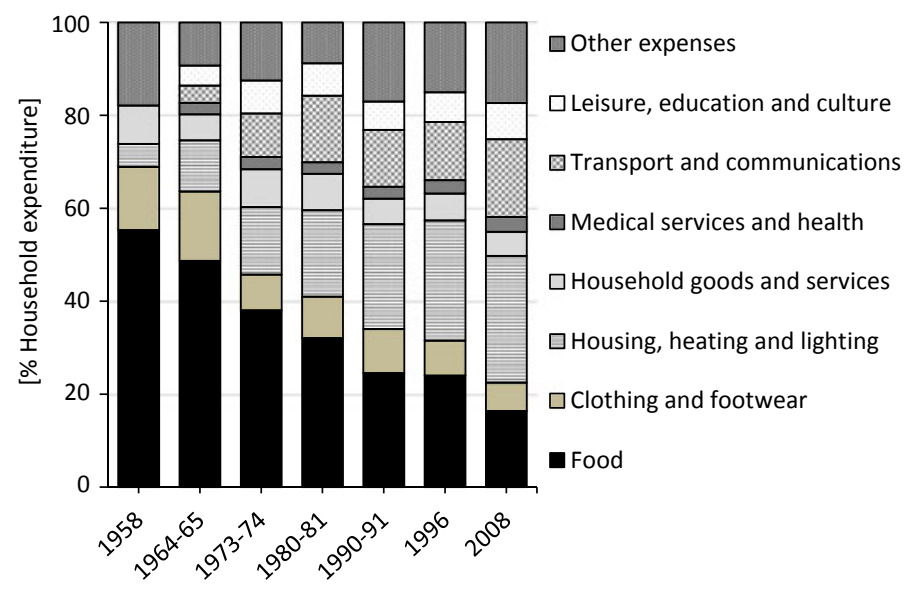

Graph 4.12 Percentage of average national household expenditure according to categories, percentage of the year 2008 euros. Note Other 1958 expenses include medical services, transport, and leisure. Source Compiled by the authors based on the Household Budget Surveys of the National Institute of Statistics (INE) The "1958 General Expenditure" category only exists for that year and as from 1964-65 it is divided into "Other expenses", "Leisure, Education and culture", "Transport and communications", "Medical services and health"

The expenditure structure and its evolution show that the amount of money dedicated to food grew between 1958 and 1973-74 and then decreased until 2008 in constant euros from that year. The amount invested in food by households went from $€ 5725.11$ in 1958 down to $€ 5190.08$ in 2008 , a drop of $10.3 \%$. However, the series shows an even greater percentage drop in food expenditure in relative terms, from $55.30 \%$ in 1958 to $16.37 \%$ in 2008 .

Decreasing food expenditure has been common to rich Western countries and results from the combination of two phenomena: on the one hand, the growth of per capita income and household income, leading to bigger spending on other nonfood goods; and on the other, constant food price reductions, despite remarkable diet shifts towards meat and dairy product intake (González de Molina et al. 2017; Collantes 2017a, b). This cheapening of shopping baskets has, as we shall see, a devastating impact on the agricultural sector, reducing the prices received by farmers and agricultural income. We will also see that this economic policy was led almost indistinctly by different governments, to lower wages and enlarge budget margins enabling households to purchase other types of goods and services.

In contrast, the "Housing, heating and lighting" item followed an opposite trend, from a meager $4.96 \%$ in 1958 to $27.26 \%$ in 2008 . This item reflects the extent of household expenditure on housing and the weight of mortgage charges during the real estate boom. Expenditures related to "Transport and communications" and "Other expenses", also increased from 3.71 and 9.28\%, respectively, in 1964-65, to around $17 \%$ for both in 2008 , exceeding food expenditure. "Household goods and services" "Leisure, education and culture" and "Medical services and health 
conservation" expenses remained below $10 \%$ of household budgets, with no major changes in the series. The behavior of education and health expenditures does not seem a priori logical given that during these years, primary and secondary education became universal, access to university became widespread and health turned into an additional right. The trend can be justified by the State's gradual provision of these basic services, financed by taxes and proper to Welfare States. The public nature of these services undoubtedly left more room to acquire other goods and services (Graph 4.13).

In short, the series shows that spending on food decreased both in absolute terms and, above all, in relative terms. At the same time, the remaining household expenditure, except those dedicated to health and education, grew significantly, reflecting the constant growth of exosomatic consumption. In this sense, Spain followed a similar path to that of other wealthy countries, though belatedly, several decades later.

The Household Budget Surveys break down expenditure according to the household head's professional profile, enabling to uncover the behavior of three professional categories related to the agricultural sector. As shown in Graph 4.14, households belonging to "Farms with employees" were always above the national expenditure average, while households belonging to "Small owners with no employees" and "Day laborers" were below the average. The behavior of all three categories broadly followed the same trend as the national average. It was not possible to fully reconstruct the series due to a lack of data, therefore, we cannot ensure that this statement is true for the entire period. However, the series shows the relative "impoverishment" of small landowners with no employees who almost converged with day laborers in the mid-1990s. As we will see later (Graph 4.20), small farms paid the price of the impoverishment. Farms below 20 ha constitute the farm-size segment where most farms disappeared. Moreover, the moments of greatest decline coincided

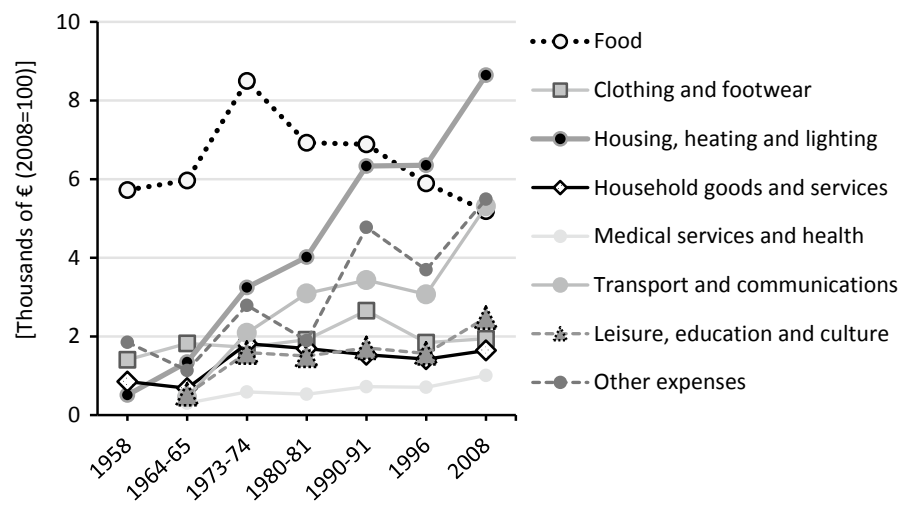

Graph 4.13 Household expenditure by category, in 2008 euros. Other expenses for 1958 include services, transport, and leisure. Source Compiled by the authors based on the Household Budget Surveys of the National Institute of Statistics (INE). The "1958 General Expenditure" category only exists for that year and is divided in 1964-65 into "Other expenses", "Leisure, Education and culture", "Transport and communications", "Medical services and health" 


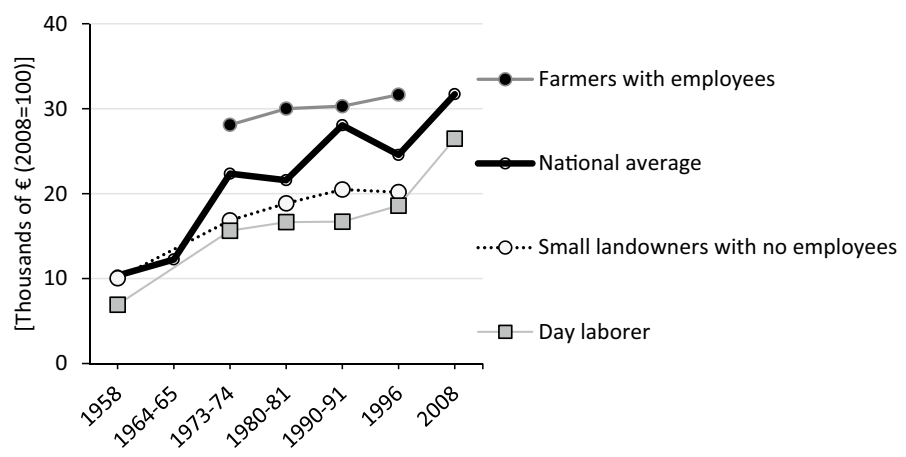

Graph 4.14 Household expenditure according to households' main breadwinner profession, in thousands of constant year 2008 euros per year and family. Source Compiled by the authors based on the Household Budget Surveys of the National Institute of Statistics (INE)

with that convergence process. In this sense, the CAP has not succeeded in stopping the tendency towards small farm destructions and the abandonment of activity by many owners.

A lack of data prevents us from analyzing the internal structure of household spending for these three household categories throughout the study period. However, the available data show that although there were no big differences in expenditure structure, there were variations in total expenditure size per household, as we saw in the previous section. The sources do offer information for the entire period on the "day laborers" category. It shows that day laborers spent more than average on food (Graphs 4.15 and 4.16).

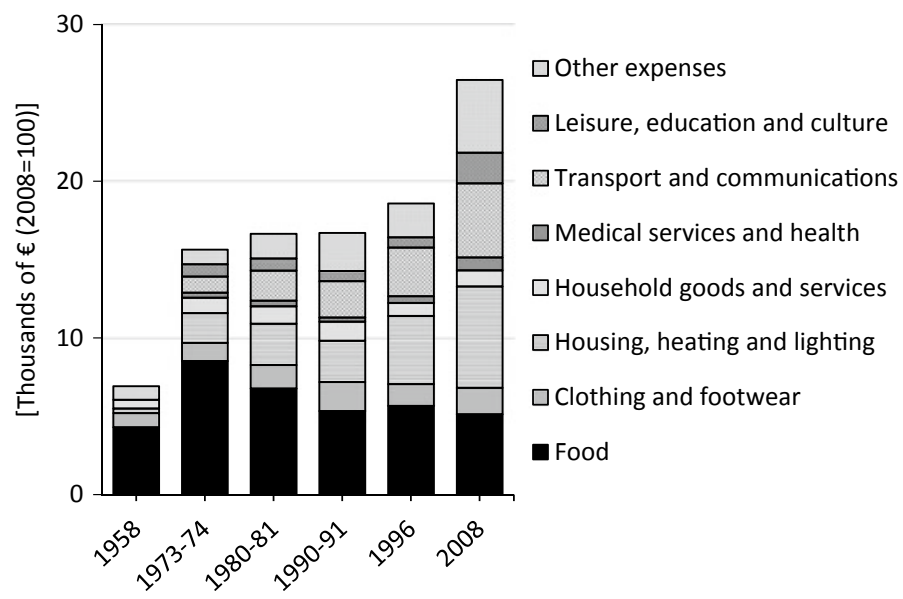

Graph 4.15 Household expenditure of day laborers according to expenditure categories, in 2008 euros. Other 1958 expenditures include medical services, transport and leisure 


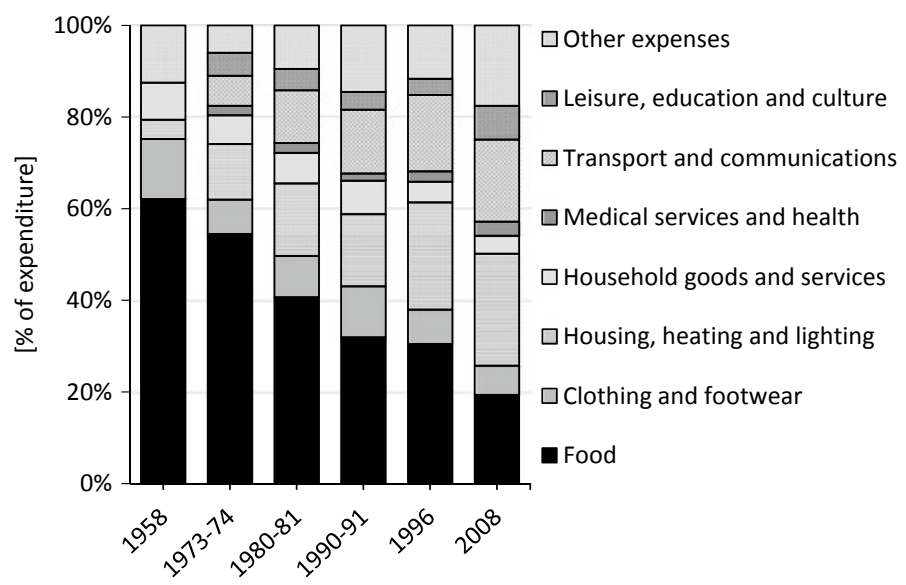

Graph 4.16 Structure of household expenditure of day laborers according to expenditure categories, in percentages of the year 2008 euros. Other 1958 expenditures include medical services, transport and recreation

To conclude, the expenditure of households who were dependent on agricultural income, except, unsurprisingly, of "Farms with employees", has consistently been below the national average since 1958. That is, access to goods and services by the majority of the agricultural population has been inferior to that of the rest of the country, especially that of day laborers and small landowners with no employees. This trend has been directly linked to agricultural activity's low remuneration, as studied above in the evolution of income.

\subsection{The State of the Agricultural Population}

What consequences have agricultural income reductions and household expenditure increases had on the agricultural population? In recent decades, one undeniable consequence has been the reduction of employment in the sector. Labor decline can be observed by analyzing the evolution of both the active agricultural population, those employed in the sector, and the number and size of farms, that is, the amount of resources constituting the fund element. We prepared the figures on the active population after 1950, (Table 4.6) based on the 1960 and 1970 population censuses and the series provided by Pilar García Perea and Ramón Gómez in their work for the Bank of Spain (García \& Gómez, 1994), covering the 1964-1992 period. The report contains employment and unemployment series based on information found in the Active Population Survey (EPA), also published by the INE. The data from the EPA for the periods 1987-2004 and 2002-2008 helped to complete the entire study, allowing us to build a consistent series from 1960 to 2008. We based our series on the homogenization work carried out by García Perea and Gómez (1994) and 
filled in the previous and subsequent years using the same methodology. This meant reworking the series, separating male from female work, relying on the years for which information was available, and the interpolation of values for the remaining years. The interpolation was performed taking into account the percentage of the male active population with respect to total active population and the percentage of male agricultural active population of total agricultural active population, thus obtaining the absolute figures of the male active population as well as total male agricultural active population. The figures for active women were obtained by deducting male agricultural active population from total agricultural active population.

To draw up the series on the working population, we proceeded in the same way, using the Bank of Spain's standardized series and later filling the years with no data until completing the series. We then distinguished male and female workers, relying on the years for which there is sufficient information, the remaining values having been interpolated. However, active women/working women data obtained this way provided incoherent data for some years in which there were less active agricultural women than female farm workers, which is obviously impossible. We corrected these deficiencies, recalculating the series on active women adding unemployed women to the number of working women. The same strategy was followed to build the agricultural unemployment series (Table 4.6).

Poor working conditions and low wages during the first decades of Franco's era explain the speeding up of rural flight, at a time when industrialization resumed in the Basque Country and especially Catalonia. It was also influenced by the acceleration of industrial growth in Central Europe, attracting large quantities of emigrants from the south of the continent. It is no coincidence this coincided with the end of Spain's diplomatic isolation and integration into international markets. The rural population's shift to industry led to higher wages in the countryside and increased labor costs, favoring the introduction of tractors, harvesters and other machines thus initiating the mechanization of the main tasks in the field (Naredo 2004a, b). Mechanization explains, in turn, the quick decline of the active agricultural population during the

Table 4.6 Active agricultural population (in thousands of people) and its percentage over total active population and total population

\begin{tabular}{r|r|r|r|r|r|r|r}
\hline Year & Men & Women & $\begin{array}{c}\text { Active } \\
\text { agricultural } \\
\text { population }\end{array}$ & $\begin{array}{c}\text { Active } \\
\text { Population (*) }\end{array}$ & $\%$ & $\begin{array}{c}\text { Total } \\
\text { inhabitants }\end{array}$ & $\%$ \\
\hline 1950 & $4,827.6$ & 409.5 & $5,237.2$ & $10,793.1$ & 48.5 & $28,172.2$ & 18.6 \\
\hline 1960 & $4,204.9$ & 425.4 & $4,630.4$ & $11,634.2$ & 39.8 & $30,776.9$ & 15.0 \\
\hline 1970 & $3,404.4$ & 401.8 & $3,806.2$ & $12,362.7$ & 30.8 & $34,041.5$ & 11.2 \\
\hline 1981 & $1,818.4$ & 454.7 & $2,273.2$ & $13,320.0$ & 17.1 & $37,682.3$ & 6.0 \\
\hline 1991 & $1,110.3$ & 432.5 & $1,542.8$ & $15,602.2$ & 9.9 & $38,872.2$ & 4.0 \\
\hline 2001 & 833.8 & 342.9 & $1,176.7$ & $17,814.6$ & 6.6 & $40,847.3$ & 2.9 \\
\hline 2008 & 734.8 & 291.2 & $1,026.1$ & $23,065.5$ & 4.4 & $45,668.9$ & 2.2 \\
\hline
\end{tabular}

Source INE (*) includes the official Spanish population and immigrants 
sixties. In 1950, they represented more than 5.2 million active individuals, which accounted for almost half of the total active population and 18.6\% of the Spanish population. In 2008, this figure came down to just over one million, barely exceeding $4 \%$ of the total active population and just over $2 \%$ of the population. The total number of the agricultural active population in 1950 had thus been reduced to one fifth, whereas the total active population had more than doubled, reducing agricultural activity as a source of employment. In just over fifty years, agriculture switched from providing work to almost half the active population to employing a tiny percentage, occupying an almost marginal place. Women's labor incorporation also took place in the agricultural sector, despite continued employment destruction. Women who used to represent only $8 \%$ of the active population accounted for $29.1 \%$ in 2000 and $28.4 \%$ in 2008. Women's agricultural work, which had always existed, became a little more visible.

Table 4.7 and Graph 4.17 show the joint evolution of the active agricultural population, both employed and unemployed, from 1950 to 2008. The number of active

Table 4.7 Evolution of active persons, employed, and unemployed persons in the agricultural sector, 1950-2008 (thousands of people)

\begin{tabular}{r|r|r|r|r|r|r}
\hline Year & Active & $1950=100$ & Employed & \% Active & Unemployed & \% Active \\
\hline 1950 & 5237.2 & 100 & n.d. & - & 52.8 & 1.1 \\
\hline 1960 & 4630.4 & 82 & $4337.7 *$ & 100.0 & 45.2 & 0.9 \\
\hline 1970 & 3806.2 & 73 & 3806.2 & 100.0 & 30.2 & 0.8 \\
\hline 1980 & 2273.2 & 43 & 2258.5 & 99.3 & 109.0 & 4.8 \\
\hline 1990 & 1542.8 & 29 & 1485.7 & 96.3 & 200.2 & 13.0 \\
\hline 2000 & 1176.7 & 22 & 1012.1 & 86.0 & 216.3 & 18.4 \\
\hline 2008 & 1026.1 & 19 & 828.2 & 80.7 & 137.7 & 13.4 \\
\hline 2016 & 1016.8 & 19 & 774.5 & 76.2 & 242.2 & 23.8 \\
\hline
\end{tabular}

Source Compiled by the authors based on sources referred to in the text

*The data corresponds to 1964 . There were the same number of active individuals that year

Graph 4.17 Evolution of the active population, employed and unemployed persons in the agricultural sector (1950-2008) in millions of people

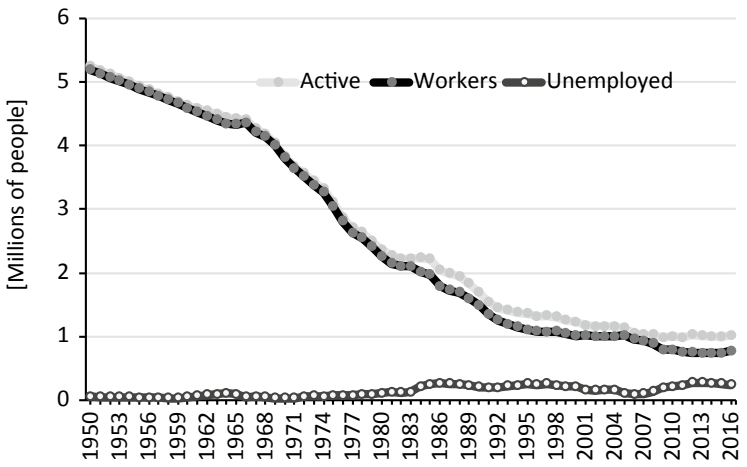


persons is almost matched by the number of persons working until the end of the eighties. From the early nineties onwards, the figures begin to diverge, with increasing numbers of unemployed persons. The unemployment figures gathered by the sources before 1980 doubtlessly refer to workers that were unemployed for several months a year but received a specific amount of daily wages.

As mentioned earlier, the way in which unemployment was recorded over the last decades does not adequately capture the seasonal and irregular nature of work, proper to some agricultural contexts such as that of Spain's, where labor demand is concentrated at specific moments of the year and leaving active persons out of work the rest of the year. It is common for agricultural employees to enter and leave unemployment lists once or several times during the year. The extent of this phenomenon has undoubtedly dropped in recent years due to the sector's drastic reductions in employment offers and because of unemployment benefits, which sometimes provide a more stable income than the job market itself.

According to the trend reflected in the graph and table, two distinct periods can be distinguished: a first period, from 1950 to 1980 , is characterized by a narrow relationship between active and employed persons, with very low unemployment rates of around $1 \%$, that are well under the rates considered as full employment rates; a second period from 1980 to 2008 is characterized by an increase in agricultural unemployment, that is moderate at first and then goes on to reach nearly $20 \%$ in year 2000 . The Spanish economy's turnarounds and the rate of agricultural industrialization explain that the active and employed agricultural population dropped equally over the first period; therefore, agricultural unemployment (excluding seasonal unemployment) was practically non-existent. In a context in which industry and services' labor demand stimulated migrations from the countryside to cities, mechanization was the logical response to the rise in labor costs, especially for medium and large farms. Yet both processes did not necessarily evolve at the same speed. A feedback mechanism had to be established in which emigration made salaries more expensive, encouraged mechanization and decreased labor demand. Surplus workers chose to emigrate, making salaries even more expensive and encouraging mechanization. This mechanism kept agricultural unemployment down and continued to work as long as labor continued to be demanded by industry and services.

However, with the Political Transition and the establishment of the democratic regime, the effects of the 1973 oil crisis and subsequent industrial restructuring all led to increasing unemployment rates. According to the data of the EPA, unemployment rose above $10 \%$ in the early eighties and reached $25 \%$ in the mid-nineties, after a brief slow-down. Emigrating to cities in search of stable employment was no longer a solution. The destruction of employment in agriculture, resulting as we have seen from mechanization, accelerated and raised unemployment rates in the agricultural sector above 4\%. That rate was exceeded in 1980 and would not stop increasing in subsequent years. The unemployment rate went from $5.6 \%$ in 1981 , to $12 \%$ in 1990, to $17.6 \%$ in the year 2000 and exceeded $20 \%$ in 2010. Currently (2016) the agricultural unemployment rate is around $23.8 \%$, after having exceeded $26 \%$ in 2014. The shortage of alternative jobs has aggravated unemployment, but this does not explain why it has continued to rise since the early seventies and especially since 
the eighties. The rate has been rising year after year (except during the three years between 2005 and 2007), reaching a peak in 2014. This means that unemployment in the sector is structural. As we will see in later sections, the reduction of labor costs has constituted the most widespread strategy to compensate continued reductions in farm income in real terms. In fact, labor costs accounted for $60.4 \%$ in 1964-5 and $31.9 \%$ in 2008 , i.e., practically half. In other words, income increase per worker has come at the expense of employment. The intensity of this increase, as we will see below, jeopardizes the sector's generational replacement.

\subsection{Changes in Farm Structures}

The transformations described in the previous sections were correlated with farm structures. Their evolution can be reconstructed from two main sources: the "Agrarian Censuses" (1962, 1972, 1982, 1989, 1999, 2009) and the "Surveys on the Structure of Agricultural Holdings" (between 1987 and 2016). It is not possible, however, to build a consistent series using both sources. The structures survey only includes a very small share of the farms below one hectare, that are collected in the agricultural censuses. In addition, categories and definitions vary among the different censuses, especially regarding the composition of the utilized agricultural area (UAA). Although it is possible to solve this problem and homogenize census data (López Iglesias 2006), it is not possible with the latest agricultural census (the 2009 census), that uses the same definition as that of the structure surveys. Therefore, it is comparable with these surveys but not directly with the previous censuses. We thus dispose of two types of different series: one based on censuses, between 1962 and 1999, and another based on surveys as well as the latest agricultural census, between 1987 and 2016. Although they cannot be combined, they do at least show the trend followed regarding the amount and structures of farms.

Graphs 4.18 and 4.19, respectively, show the evolution in the number of farms and total area per farms. According to the censuses, the number of farms decreased between 1962 and 1999 by 39\%, while the average area per farm increased by $55 \%$. According to the structure surveys, the number of farms decreased by $48 \%$ and the average area grew by $71 \%$, due to a 79\% increase in the UAA per farm between 1987 and 2016. The figures thus show a considerable decline in the number of farms and a parallel increase in their average size. Regardless of comparison problems between the sources that prevent us from giving an exact figure, we can say that around two-thirds of farms disappeared during the agricultural industrialization process.

However, the rate of decline was not constant. Several periods can be distinguished. Between 1962 and 1972, the number of farms dropped quite sharply $(-12.4 \%)$, and average surface areas also rose notably $(16.9 \%)$, a phenomenon undoubtedly linked to the beginning of the industrialization process and the end of traditional organic agriculture (López Iglesias 2006). However, the rate slowed down during subsequent intercensal periods, differing considerably from the restructuring processes of neighboring countries (López Iglesias 2006). The number of farms 


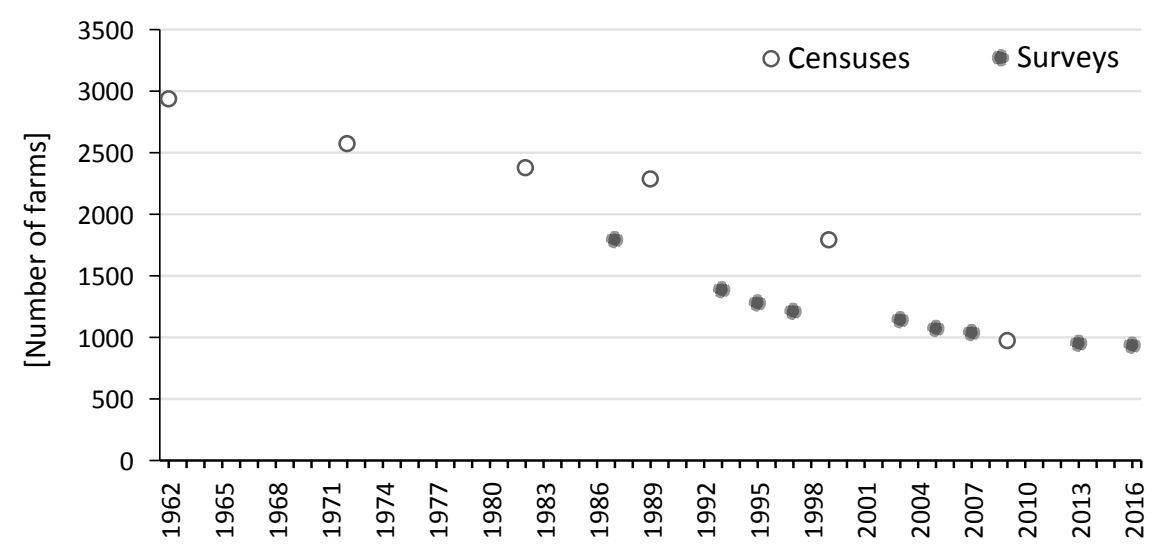

Graph 4.18 Number of agricultural holdings (in thousands) according to the agrarian censuses and the survey on agricultural holdings. Source Agrarian censuses and structure surveys

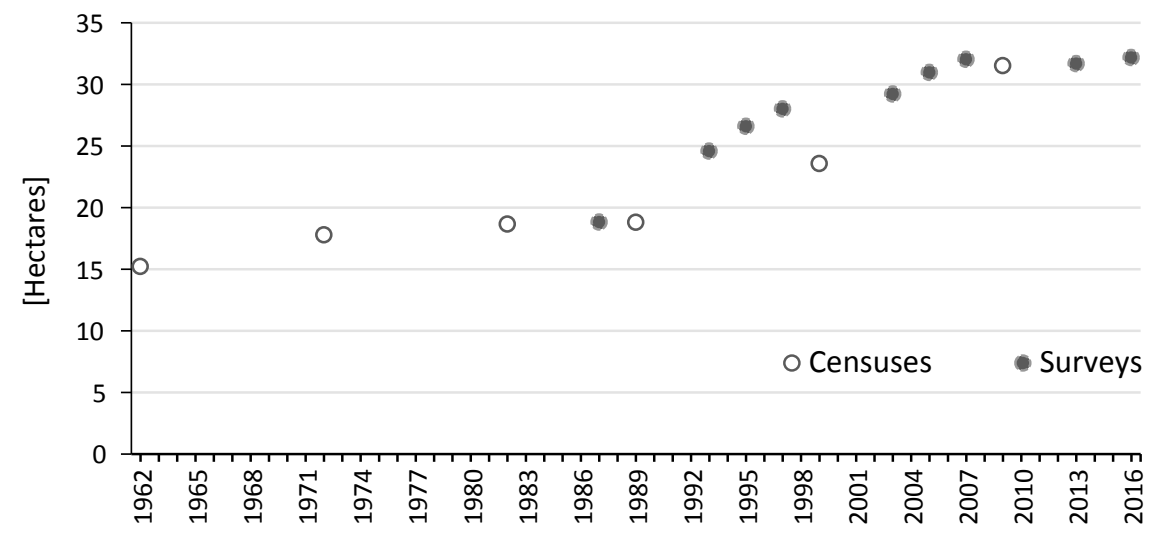

Graph 4.19 Total surface area per farm, in hectares. Source Agrarian censuses and structure surveys

decreased by $7.6 \%$ between 1972 and 1982 and by 3.8\% between 1982 and 1989. It was after Spain joined the European Union that the restructuring process accelerated again and much more vigorously. Between 1989 and 1999, the number of farms decreased by $21.7 \%$. The figures provided by the structure surveys are even more striking: between 1987 and 1997, the number of farms decreased by 32\%. Regardless of the differences between the two sources, Spain's entry into the EU clearly had a substantial impact, accelerating the disappearance of farms and the concentration of land. Average surface areas grew by $48.9 \%$ between 1987 and 1997 and the UAA per farm grew by $53.3 \%$. Since the turn of the century, farm has continued to disappear, but at a much slower pace: between 1997 and 2007 their numbers decreased by $14.2 \%$, while between 2007 and 2016 they dropped by $9,9 \%$ in the midst of 
the economic-financial crisis. However, a new phenomenon took place in this later period: for the first time since Spain joined the EU, farm destruction has not been accompanied by an increase in farm surface area. This is a particularly relevant fact, since it implies that over 3 million hectares disappeared from farm surveys between 2007 and 2016 due to cessation of activity and, most likely, land abandonment. ${ }^{6}$

As mentioned, the decline in the number of farms came with an increase in the average size of remaining farms. Graph 4.20 shows the evolution of the number of farms according to strata from the structure surveys. Findings by López Iglesias (2006) regarding the previous period are confirmed by agrarian censuses for the 1987-2016 period. Although the number of farms decreased in all strata between 1987 and 2016 (with the exception of the upper stratum of farms equal to or above 100 hectares), smaller farms experienced the most difficulties in adapting to the industrial agricultural model. Farms under 10 hectares decreased by more than 50\%; farms between 10 to 20 hectares dropped by $40 \%$ and farms between 20 and 30 hectares by $26 \%$. Larger farms adapted much better to the process of industrialization. Since 2007, farms over 30 hectares have not even experienced any drop in their number.

For many economists, the disappearance of countless farms has been the result of a process of "classical structural adjustment" (Arnalte and López Iglesias 2002; Arnalte 2006b), a logical result of the sector's own industrialization. Its consequences are valued positively insofar as it has allowed to strengthen a smaller number of economically profitable farms. This process would also be environmentally positive

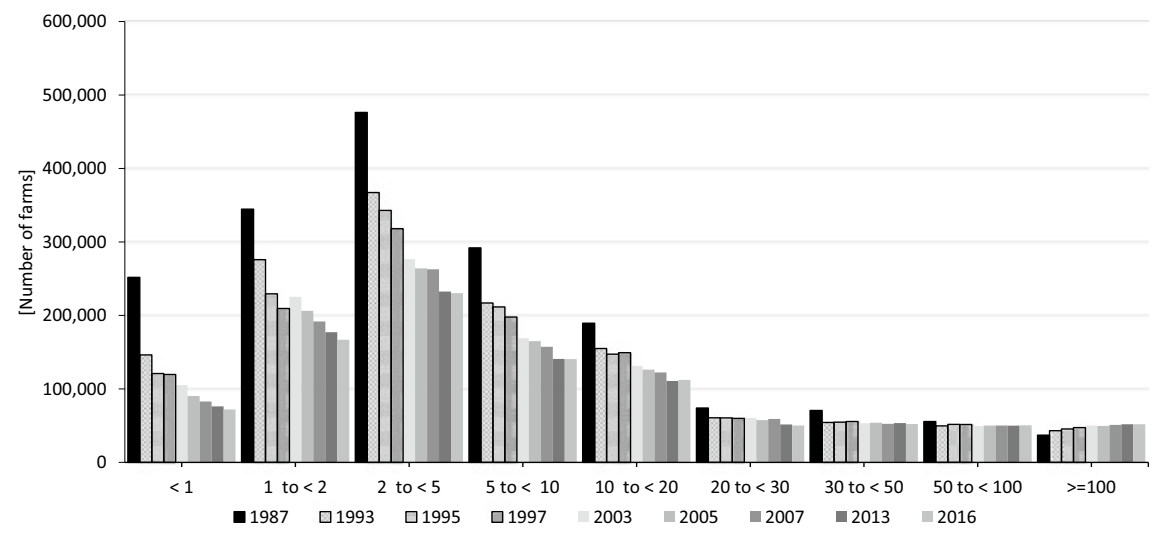

Graph 4.20 Evolution of the number of farms per size strata in hectares. Source Agrarian censuses and structure surveys

\footnotetext{
${ }^{6}$ Land abandonment also took place in previous years, although it is impossible to specify its rate or size due to the impossibility of comparing censuses and surveys, or even censuses from 1999 and 2009). The data from the censuses show relative stability of surface area surveyed between 1962 and 1982 (which even increased between 1962 and 1972) and a drop of more than 2 million hectares between 1982 and 1999. The drop in registered surface area in this period did not prevent average farm size from increasing considerably anyway.
} 
since, according to the same argument, larger farms could provide environmental services at a lower cost. In contrast, other authors present a darker picture, considering that the disappearance of farms has negative social and environmental consequences, given that farms' purposes go beyond purely economic interests (Arnalte 2006a). Nonetheless, these authors do not question either whether adjustments are inevitable. It is, of course, debatable whether the adjustment is economically positive. In no way is it positive from the point of view of farmers themselves. Nor from the perspective of a functioning agricultural market model that differs from the prevailing model, in which income from the agricultural sector is continually transferred to other sectors of activity. This transfer is encouraged by the idea that agricultural policy should aim at ensuring cheap food in order to lower living costs.

Farm destruction and activity abandonment also explain that leasing spread as a mechanism for land mobility (López Iglesias 2006) and the rise of commercial companies. As we will see below, demographic aspects (average age of farm owners) as well as production aspects (work on the farm) must also be taken into account to understand these dynamics and future prospects. The data in Table 4.8 shows the link between farm destruction, which accelerated between 1989 and 1999 as we saw, and the rise of land leasing. The structure surveys show the same relationship, although in this case (Table 4.9), growth is especially visible from 1997 onwards.

López Iglesias (2006) pointed out that the spread of lease over the 1989-1999 period was not only linked to the resizing of farms, but to other related processes such as the rising number of agricultural holdings managed by trading companies. This trend is confirmed for the 1993-2016 period (Table 4.10). Although the type of farm that grew the most was the production cooperative (by 204\%), its relative weight is still very small (2.4\% of total UAA). Trading companies expanded considerably (by $51 \%$ between 1993 and 2016), going from $7.1 \%$ of the total at the beginning of the period to $11.5 \%$ of UAA in 2016. During that phase, the farms' restructuring process largely consisted of companies penetrating in agricultural production activities.

Farms owned and managed by physical persons decreased for all age brackets since 1987 (Graph 4.21), but the drop was especially significant and fast in holders aged under $35(-65 \%)$, while that of holders aged over 65 decreased much less $(-21.4 \%)$. This phenomenon shows that the land's production management model was beginning to change: it followed traditional patterns in higher age segments and

Table 4.8 Evolution of the Utilized Agricultural Area (UAA) by land tenure regimes according to the Agrarian Censuses (thousands of ha)

\begin{tabular}{|c|c|c|c|}
\hline & 1982 & 1989 & 1999 \\
\hline Property & 16,836 & 17,929 & 17,632 \\
\hline Lease & 4,826 & 4,901 & 7,073 \\
\hline Sharecropping & 1,285 & 1,175 & 787 \\
\hline Others & 725 & 735 & 824 \\
\hline Total & 23,672 & 24,741 & 26,317 \\
\hline
\end{tabular}

Source López Iglesias (2006) 


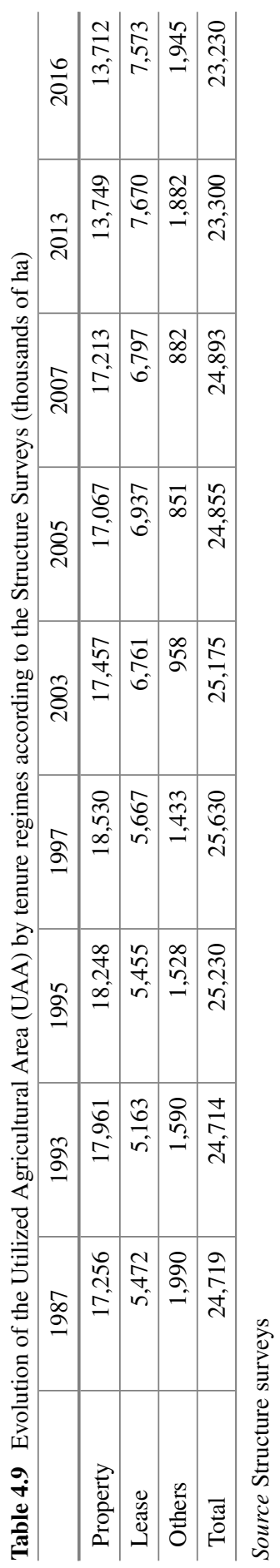


Table 4.10 Evolution of the Utilized Agricultural Area (UAA) according to legal personality (thousands of ha)

\begin{tabular}{l|r|r|r|r|r|r|r}
\hline & \multicolumn{1}{|c|}{1993} & \multicolumn{1}{c|}{1995} & \multicolumn{1}{c}{2003} & \multicolumn{1}{c}{2005} & \multicolumn{1}{c}{2007} & \multicolumn{1}{c}{2013} & \multicolumn{1}{c}{2016} \\
\hline Physical person & 18,849 & 18,679 & 17,444 & 17,114 & 16,980 & 16,212 & 16,106 \\
\hline Commercial society & 1,766 & 2,031 & 2,239 & 2,322 & 2,451 & 2,591 & 2,662 \\
\hline Public entity & 2,112 & 2,201 & 2,419 & 2,416 & 2,299 & 1,641 & 1,474 \\
\hline Production cooperative & 183 & 169 & 211 & 230 & 260 & 580 & 557 \\
\hline Other legal status & 1,804 & 2,149 & 2,863 & 2,773 & 2,903 & 2,277 & 2,432 \\
\hline
\end{tabular}

Source Structure surveys

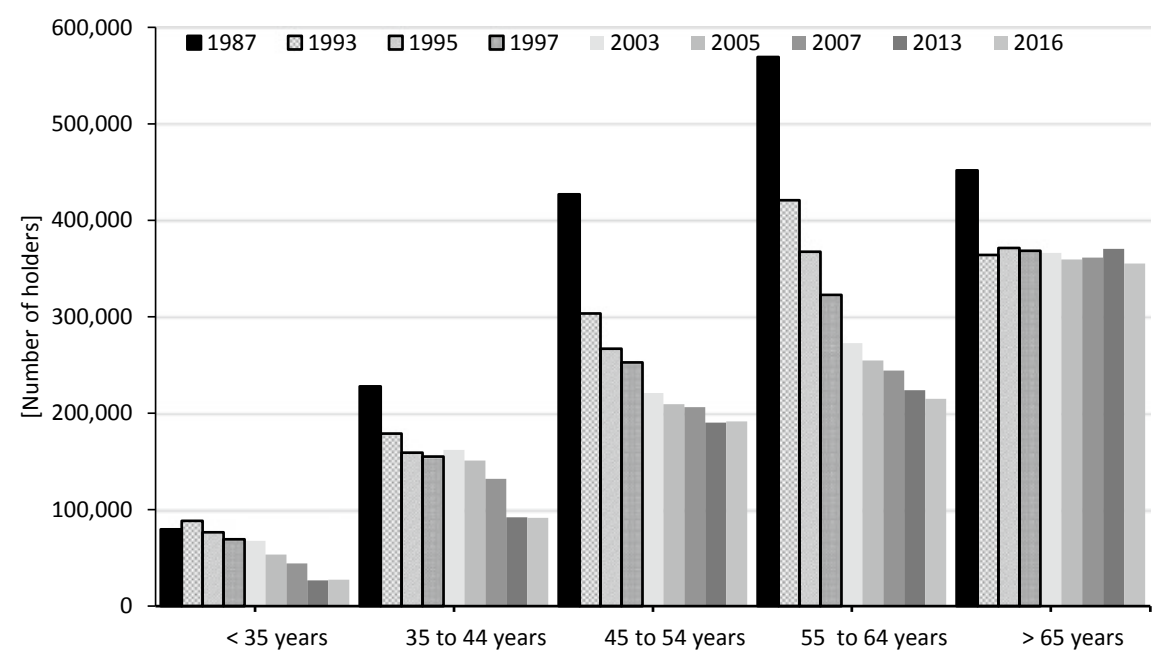

Graph 4.21 Age of farm holders, number of holders. Source Farm structure surveys

vice versa. As a result, demographic and production factors explain the changes in land tenure regimes and farm legal personalities, amid the disappearance of a large part of farms due to the cessation of activity.

In this respect, the aging of farmers is taking on worrying proportions and calling into question both the agricultural character of households and the survival of farms. Indeed, the classification of farmers according to age groups shows a very significant trend towards aging, clearly reflecting a lack of generational change. The model has shifted from a production model mainly supported by owners aged $45-64$ years $(56 \%$ in 1987) to a model in which up to $40 \%$ of the owners are over 65 years. This leads us to question the future of countless farms, and all the more so if one takes into account the ever declining weight of owners aged under 44 years, and especially those under 35 years. 
The evolution of farm work (measured in annual working units, AWUs) also points in the same direction. The number of AWUs on farms decreased by $50.7 \%$ between 1987 and 2016, over three different periods: between 1987 and 1997, AWUs fell by $32.4 \%$; between 1997 and 2007, the rate of decline was much slower (11.9\%); and between 2007 and 2016 (17.2\%), it accelerated again. This trend is consistent with figures on the evolution of the active agricultural population and income evolution described above. The data in Graph 4.20 indicate that the reduction concentrated on household work (-44\%). Conversely, fix paid work grew by $67 \%$ and casual employment decreased by $11 \%$. The growing trend in fix paid work is consistent with the changes regarding the legal personality of holdings described above and, especially with the spread of commercial companies.

The data shown in graph 4.22 generally shows that not only did total work on farms decrease, since many farms shut down, but the amount of work performed within surviving farms also dropped. This confirms that farmers' most common strategy to compensate drops in agricultural income has been work reduction. The graph also shows that employment was destroyed mainly within the household context and to a much lesser extent in casual employment. This phenomenon faithfully reflects households' progressive deagrarization, as they seek employment for their members, especially for their children, in other economic activities (Collantes 2007). Finally, fix paid work grow this related to the increase in the average size of farms, which are now more intensive than in the past and therefore require more constant use of labor; but it is also linked to the proliferation of trading companies that manage them and the emergence of companies dedicated to land management and the provision of agricultural services for others. This latter model, usually of a trading society nature, is ever more widespread due to cessations of activity, but also because of the part-time farming phenomenon that many operators are obliged to engage in given their reduced income.

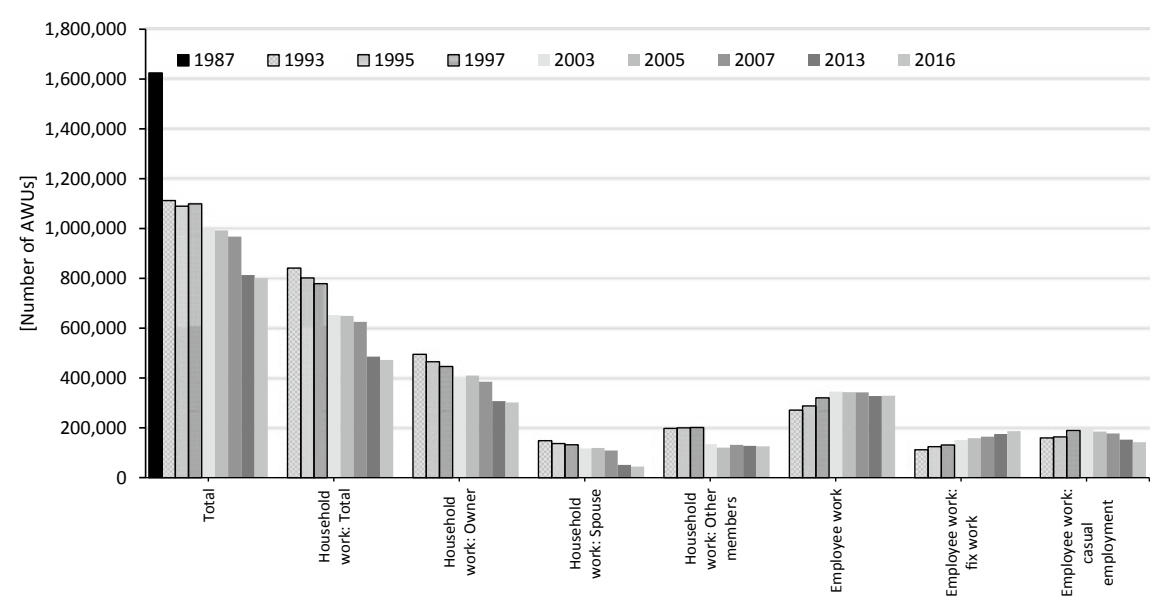

Graph 4.22 Number of farm Annual Working Units (AWUs.) Source Farm structure surveys 


\subsection{Breakdown of Agricultural Income and Coverage of Household Expenditure}

Table 4.11 shows income broken down into remuneration of employees, net operating surplus and business income, which is equal to the net surplus minus the amounts paid by farms for rent, interest and indirect taxes. A similar evolution is found all around, except for business income that grew less, due to farms having to face bigger financial payments than in the past. Current values were used. However, agricultural income has been falling in constant values relatively sharply since the early sixties and this drop has become more significant in recent years. Almost half of agricultural income's real value has been lost since then.

Household expenditure, however, has followed an opposite trend and has risen steadily. This has been possible because of the reduction in number of farm workers, leading to growing income per person. Nonetheless, we need to know to what extent the growth of income per employed person has succeeded in covering average household expenditure. Table 4.12 compares the income per employed person, total income per agricultural worker and entrepreneurial income (the income perceived by farm owners) with the evolution of average Spanish expenditure from 1964 to 2008 and rural expenditure, referred to as "suburban" by the Household Budget Surveys. We only took into account the years for which we dispose of the surveys. Agricultural income, remuneration per agricultural worker and entrepreneurial income show income per farm owner or per employed person, while average expenditure is per household. They are not, therefore, strictly comparable. However, and with due caution, both variables allow us to apprehend the capacity of agricultural income to cover Spanish household average expenditure.

The data in Table 4.12 suggest there were two different periods. A first period, from the mid-sixties to the mid-nineties, in which income received by farmers and agricultural workers was clearly insufficient to cover household expenditure, whether in terms of national average or rural average. This largely explains differences in living standards between rural and urban spheres that were particularly significant during those years. A second period started in the mid-nineties, in which income from agricultural activity grew above household spending, but only thanks to the destruction of employment and the cessation of activity of many farms, as we will see below. It was not that agricultural incomes improved: they continued to deteriorate in constant terms but were distributed among fewer farmers and agricultural workers.

In short, in the early sixties, agricultural activity allowed to cover the household expenditure of the owner of an average farm. However, the steady drop in income and increases in average household spending significantly harmed farmers' living standards until the mid-1990s. Most farmers were able to cope by increasing production and reducing costs. The technologies associated with the industrialization of agriculture-fertilizers, phytosanitary products, improved and hybrid seeds, irrigation and mechanization-made it possible to increase productivity, even in very small farms. To the extent that increases in land productivity made it very difficult to save on inputs, the strategy of labor cost reduction became widespread. Indeed, the 


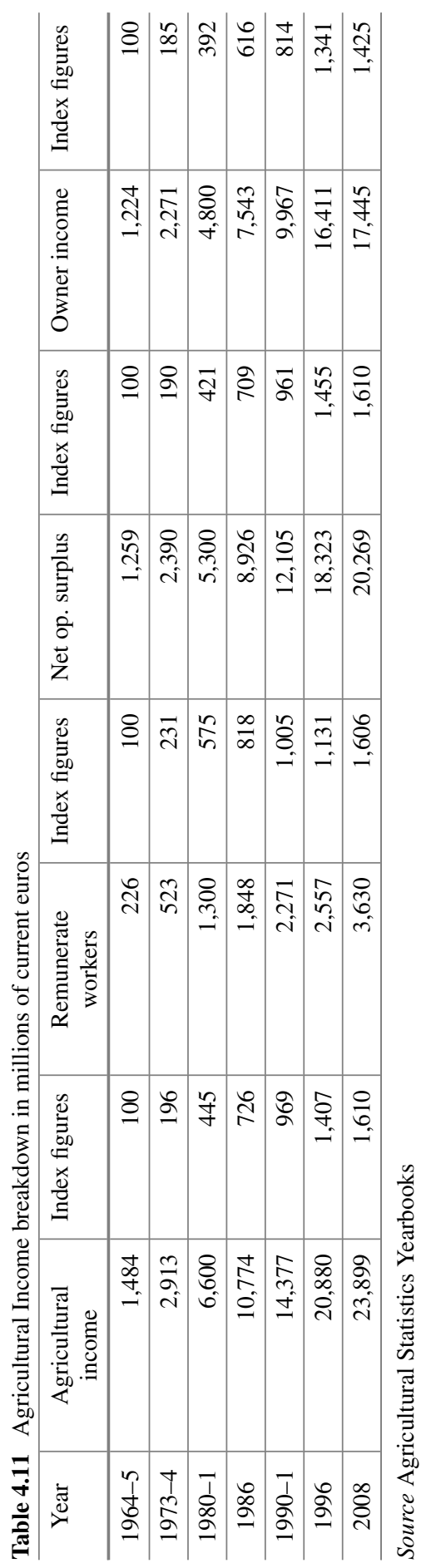




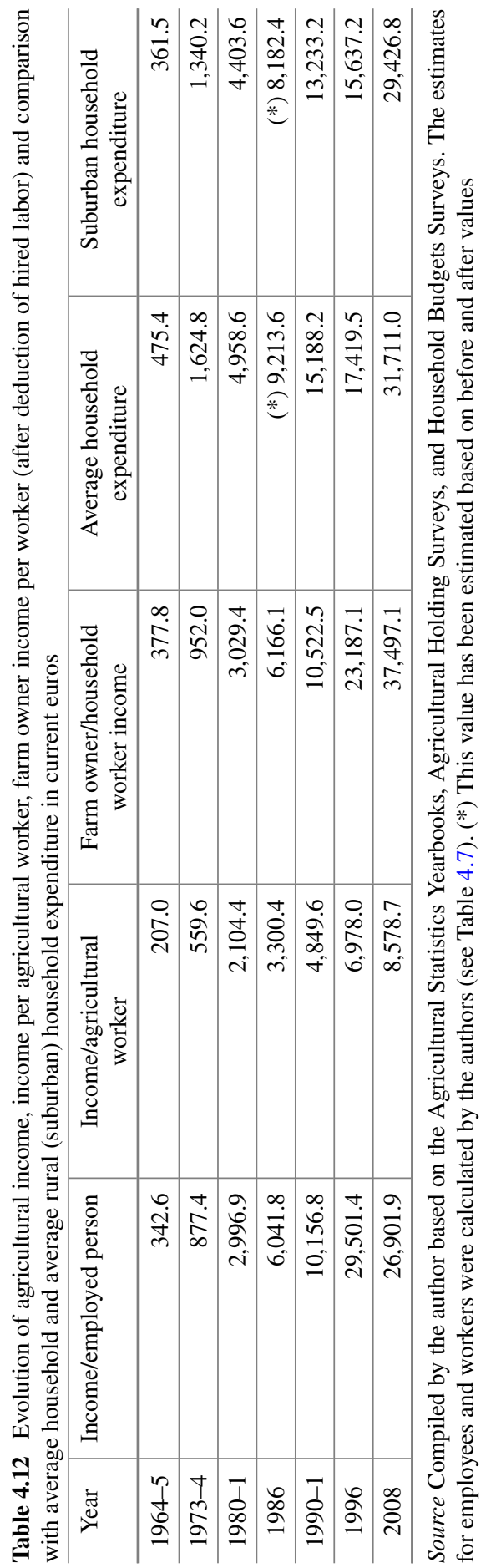


weight of wages on agricultural income declined steadily throughout the period, representing 60\% in 1964-5 and 31.9\% in 2008. However, income did not even become high enough to cover average rural household expenditure, largely because of the increase in intermediate costs and the rapid growth of household spending.

Possibilities of raising productivity through greater use of inputs or replacing labor with machines, however, were diminishing, especially in inland Spain. The conversion of rainfed lands into irrigated lands became increasingly difficult and only viable in traditional areas thanks to irrigation modernization programs. The use of chemical fertilizers reached a peak in the late nineties and the use of energy in mechanical traction would only recover early-nineties levels in 2008. Technologies that had led the industrialization of Spanish agriculture were of decreasing utility, especially for farms with low yields that could barely achieve higher incomes by incorporating inputs aimed at greater production. The most widespread strategy continued to be that of increasing labor productivity and farm size, but this strategy was beyond the reach of many farmers, leading to cessations of activity as well as farmland and pasture abandonment. This, in turn, explains employment destruction and the disappearance of countless farms in recent years, as described in the previous section. This job destruction has been taking place in a different context since the nineties: it is no longer possible to relocate agricultural labor surplus in industry, construction or services. Therefore, agricultural unemployment has begun to grow strong.

Employment and farm destruction are thus insufficient to reverse falling income, that has structural causes as we have seen. "Classical structural adjustment" has only alleviated the decline; but we cannot truly speak of a structural adjustment as it could be never-ending if no changes are made to current institutional arrangements. Current arrangements maintain an unbalanced relationship between prices received and prices paid as well as constantly declining income. In other words, decent income is only being achieved by suppressing jobs and farms, i.e., through the sector's selfdestruction.

Moreover, agricultural income has not been distributed evenly. Farm structures have been and continue to be deeply unequal both in terms of size and economic viability. Countless small farms have been unable to sustain the same consumption standards as the rest of the population. They have implemented intensification and specialization strategies to achieve them. However, not all farms have been capable of applying these strategies and have ended up abandoning their activity. Data from farm structure surveys is explicit. Between 1993 and 2007, the Gross Margin per farm (approximately equivalent to GVA), measured in numbers of ESUs, ${ }^{7}$ increased from 7 to 20.7 (in current prices). With this margin, the possibilities of covering average household expenditure increased (from 64 to 85\%). Farms whose Gross Margin reached amounts equal to average household expenditure also increased (from 14\% of farms in 1993 to 27\% in 2007). However, half the farms with less than 6 ESUs

${ }^{7}$ ESU: European Size Units. Corresponds to $1200 €$. 
disappeared. Farms above 16 ESU $(€ 19,200)$ doubled and those under 40 ESUs more than tripled. As a result, the increase in gross operating margin came at the expense of the disappearance of almost a quarter of farms and the average size increase of the remaining farms. A systematic relationship between farm viability and degree of coverage cannot be established, given that other factors linked to income from other gainful non-agricultural activities exist. But these data show that a major share of farms continued to be at risk of disappearing, despite this percentage having fallen from $86 \%$ in 1993 to $81 \%$ in 2007.

Between both years, Gross Margin per farm increased by $81 \%$ in constant euros. Farmers achieved this increase in different ways. On the one hand, by increasing the physical size of their farms, as we saw in Graph 4.19, and on the other, by orienting production towards higher gross margin products. Graphs 4.23 and 4.24 show the technical-economic orientation of farms in 1987 and in 2007. They show the four product orientations offering highest gross margins, but do not show all production orientations. Four others have also been included: they are below the average but have notable territorial impact. As can be observed, intensive livestock activity in 1987, based on monogastric animals, pigs and poultry, quadrupled farms' average gross margin. Intensive livestock thus represented the highest gross income-earning activity. This activity was followed by various crops and horticulture, cereals and milk cattle. At the other extreme, we find crops such as olive groves, viticulture, fruit, and citrus. This is certainly due to the territorial weight of low-yield farms. In 2007, this orientation had hardly changed, although livestock farms dedicated to the breeding of monogastric animals (granivores) had raised their gross margin,

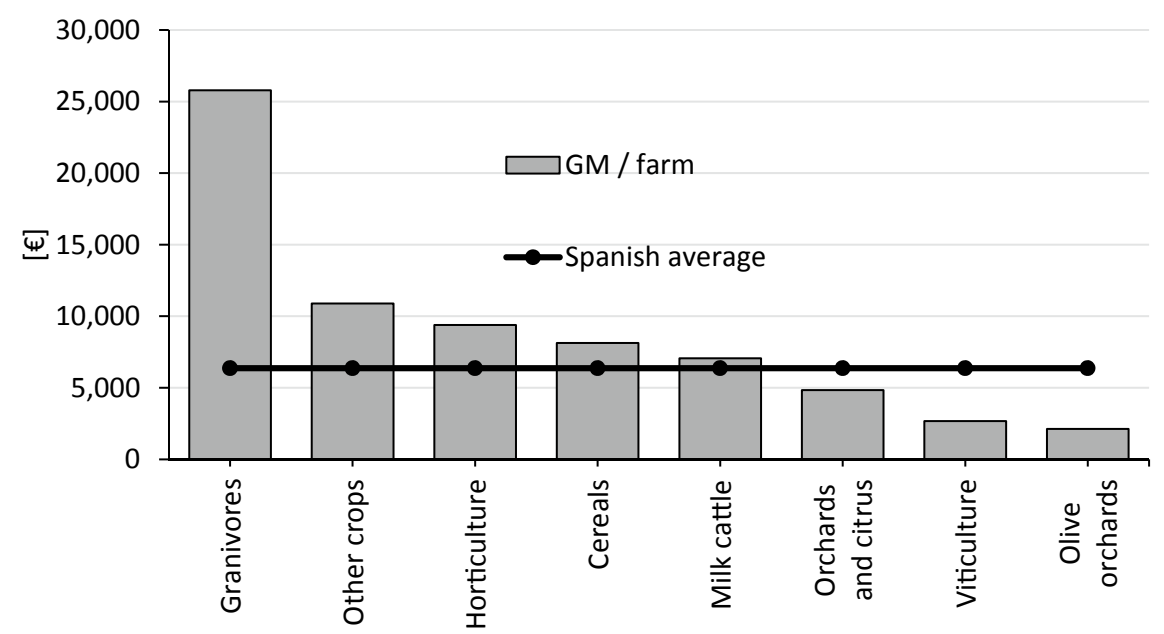

Graph 4.23 Gross margin (GM) per farm according to productive orientation, year 1987, euros. Source Farm structure surveys 


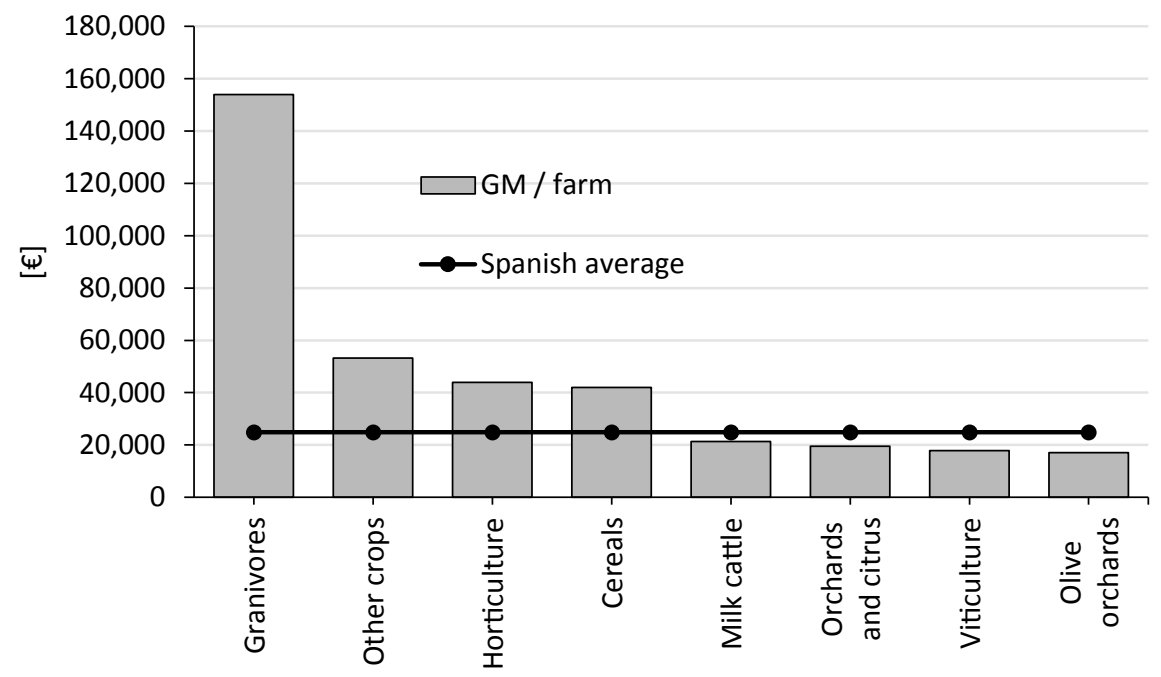

Graph 4.24 Gross margin (GM) per farm according to productive orientation, year 2007, euros. Source Structure surveys

reaching 6 times more income than the average. Horticultural farms come next, due to the weight of farms under plastic, various crops, and dairy farms. Farms presenting lowest gross margins continued to be viticulture, fruit, citrus, and olives, accompanied by farms dedicated to cereal production. These farms have survived only thanks to subsidies that are now almost completely decoupled from production. They are very dependent on the European Economic Community budget and successive CAP reforms. Agricultural holdings of great territorial impact, located in Spain's interior, are still seriously at risk of disappearing if the current regulatory framework does not change.

In 1987, granivores, various crops and horticultural production generated income above average rural household expenditure. In 2007, production margins had risen, matched by that of milk cattle. In short, the graphs show that gains in European size units (ESU) were realized through a clear orientation towards production with higher gross income, especially towards intensive livestock and crops under plastic. It also shows that, once the possibilities of increasing labor and land productivity diminished, the possibilities of tackling drops in prices received by farmers consisted of livestock and horticultural specialization. Both orientations have led to growing external inputs in energy terms, that is, they have increased the scope of Spanish agriculture's intensification and specialization. In the case of pork and poultry production, high gross margins are possible thanks to massive imports of very cheap feed based on corn and soybeans. We will come back later to this issue and the socioenvironmental impacts generated in the countries of origin. Overcoming agriculture's 
profitability crisis has thus brought about ongoing intensification and specialization of horticultural production and the sector's livestocking. Both processes have accentuated environmental sustainability problems analyzed in this book. Neither process has led to solutions of social equality applicable to the whole of Spain's rural society.

Inland extensive farms have been less likely to adopt more intensive production techniques such as greenhouses, for which access to irrigation and high initial investment are essential. Intensive farms have followed a similar path, although in recent years they have been relocated inland based on vertical integration systems of large livestock or meat distribution companies. Production alternatives to olives, fruit trees, almond trees, and other woody crops or vineyards have been limited. However, certified organic production has represented a solution adopted by extensive farms. The latter have achieved income supplements thanks to agri-environmental measures allowing them to increase the number of ESUs. Extensive cattle ranching, woody crops and rainfed cereals are good illustrations. These types of farms accounted for $83 \%$ of areas classified as organic or reconverted as of December 31, 2008. At the end of 2011, over half of extensive livestock (53.7\%) became organically managed in Andalusia (González de Molina 2012).

Organic agriculture has also been contributing to maintaining agricultural activity in areas of lowly competitive conventional agriculture. Regions such as the Pedroches Valley, the Sierra de Huelva, the Sierra de Segura, the North of the province of Granada, etc. contain most of Andalusia's organic surface areas. In these areas, subsidies account for a major percentage of operating surpluses (Guzmán Casado and Alonso Mielgo 2009). They offset the low productivity of rainfed treenuts, olives and cereal crops, and may even "explain" that in some cases production is not harvested. According to a study on the economic performance of organic farms conducted in 2007 in Andalusia (Soler et al. 2009), total subsidies (those from the first pillar plus agri-environmental subsidies) accounted for $43 \%$ of the value of final olive production, $71 \%$ of the production of nuts and no less than twice the value of extensive crops production. In the latter case, income was practically equal to the value of subsidies and almost 78\% in the case of nuts. Agri-environmental subsidies played an even more decisive role in organic livestock. Subsidies amounted to $69.4 \%$ of the 2005 production value. Without subsidies, income would have been reduced by $41 \%$.

Organic agriculture and livestock already account for more than 2.02 Mha in Spain, which is the first country in Europe per certified area, representing 8.7\% of the agricultural area (MAPAMA 2017a). It has halted the intensification process, though it has not necessarily stopped the use of external inputs nor completely reversed falling income trends. The process sometimes referred to as conventionalization threatens to nullify the advantages of this production model, bringing it ever closer to the conventional model (Ramos García et al. 2018). However, organic production does represent an opportunity to stop the deterioration of agroecosystems of inland Spain. Agri-environmental measures could be conceptualized as payments for environmental services. This "new" form of agroecosystem management is partly 
based on the rationale developed so far and has paradoxically emerged as a result of the non-feasibility of the described model. We will come back to this issue in more detail in the epilogue.

\subsection{Conclusions}

We can conclude that the processes of industrialization and subsequent globalization have significantly decreased the weight of the agricultural population fund element at the expense of increasing the size of the other social fund element, technical the means of production. As we saw in Chap. 3, technical means of production have acquired an excessive weight that threatens not only the environmental health of agroecosystems but also the viability of agricultural activity as we know it today. The rate of destruction of agricultural employment has reached such worrying levels, associated with rural depopulation and the "deagrarization" of rural households, that generational change and the viability of agricultural activity as such are at risk. This deterioration has intensified under the "classical structural adjustment" undergone by Spanish agriculture. The causes should be sought among the institutional mechanisms that have allowed agricultural sector income to be continually transferred to other sectors. These mechanisms make adjustments inevitable and threaten to prolong them until the sector eventually collapses, i.e., until most agricultural holdings disappear due to lack of profitability. Structural adjustment and its consequences do not, therefore, appear to be conjunctural. The agricultural sector has been adapting this way since the 1960 s at least.

It is worth asking whether the destruction of jobs and farms leading to the ongoing depopulation of our countryside may not, in fact, represent an obstacle to the necessary transition towards sustainable agriculture. To answer this question, we must challenge the prevailing evaluation narratives, and consider their relevance in our analysis. The size of the agricultural population, closely linked to the amount of work required in agriculture, has almost always been associated with development levels and economic growth. The decrease in the agricultural population is viewed, therefore, in a positive way by more conventional economists. Although it is not possible to establish this fund element's optimal size without referring to its space-time context, we cannot simply consider its evolution throughout the twentieth century in Spain as positive and put an end to the discussion. The continuity of the agricultural sector's current institutional arrangement jeopardizes the future of sustainable agriculture. It also weakens the supply of ecosystem services that are essential for all economic activity to be sustainable, both in rural and urban areas. 


\section{References}

Acosta F, Cruz S, González de Molina M (2009) Socialismo y democracia en el campo (1880-1930): los orígenes de la Federación Nacional de Trabajadores de la Tierra. Madrid. Ministerio Medio Ambiente y Medio Rural y Marino

Arnalte Alegre E (2006a) Economía política del proceso de ajuste estructural en la agricultura de los países desarrollados. In Arnalte Alegre E (ed) Políticas agrarias y ajuste estructural en la agricultura española. Madrid, Ministerio de Agricultura, Pesca y Alimentación, pp. 17-54

Arnalte Alegre E (ed) (2006b) Políticas agrarias y ajuste estructural en la agricultura española. Madrid, Ministerio de Agricultura, Pesca y Alimentación

Arnalte Alegre E, López Iglesias E (2002) Análisis del ajuste estructural clásico: trabajo preparatorio del libro blanco de la agricultura y el desarrollo rural del ministerio de agricultura, pesca y alimentación. Madrid. Ministerio de Agricultura, Pesca y Alimentación

Calatayud S, Martínez Carrión JM (1999) El cambio técnico en los sistemas de captación e impulsión de aguas subterráneas para riego en la España Mediterránea. In: Garrabou R, Naredo JM (eds) El agua en los sistemas agrarios. Una perspectiva histórica. Madrid. Argentaria/Visor, pp 15-39

Carreras de Odriozola A, Tafunell Sambola X (2005) Estadísticas históricas de España, siglos XIX-XX. Madrid. Fundación BBVA

Carrión P (1932 [1975]) Los latifundios en España. Su importancia, origen, consecuencias y solución. Barcelona. Editorial Ariel

Collantes Gutiérrez F (2007) La desagrarización de la sociedad rural española, 1950-1991. Historia Agraria 42:251-276

Collantes Gutiérrez F (2017a) Because they just don't want to: dairy consumers, food quality, and Spain's nutritional transition in the 1950s and early 1960s. Agric Hist 91(4):536-553

Collantes, Gutiérrez F (2017b) Nutritional transitions and the food system: expensive milk, selective lactophiles and diet change in Spain, 1950-65. Hist Agrar 73:119-147

Gallego D (1986) Transformaciones técnicas de la agricultura española en el primer tercio del siglo XX. In: Garrabou R, Barciela López C, Jiménez Blanco JI (eds) Historia agraria de la España contemporánea, vol 3: el fin de la agricultura tradicional (1900-1960). Barcelona. Editorial Crítica, pp 170-229

Gallego D (2001) Historia de un desarrollo pausado: integración mercantil y transformaciones productivas de la agricultura española. In: Pujol et al (eds) El pozo de todos los males. Sobre el atraso de la agricultura española contemporánea. Barcelona. Crítica, pp 147-214

García P, Gómez R (1994) Elaboración de series históricas de empleo a partir de la Encuesta de Población Activa (1964-1992). Documentos de Trabajo del Banco de España 9:1-63

GEHR (Grupo de Estudios de Historia Rural) (1983). Notas sobre la producción agraria española, 1891-1931. In: Revista de Historia Económica 1(2):185-252

González de Molina M (2001) The limits of agricultural growth in nineteenth century: a case-study from mediterranean world. Environ Hist 7(4):473-499

González de Molina M (2012) Luces y sombras del crecimiento de la producción ecológica en Andalucía durante el último quinquenio (2007-2011) Cuad Interdiscip Desarro Sosten 9:153-192

González de Molina M, Guzmán Casado GI (2006) Tras los pasos de la insustentabilidad. Agricultura y Medio ambiente en perspectiva histórica (siglos XVIII-XX). Barcelona. Editorial Icaria

González de Molina M, Soto D, Aguilera E, Infante-Amate J (2014) Crecimiento agrario en España y cambios en la oferta alimentaria, 1900-1933. Hist Soc 80:157-183

González de Molina M, Soto D, Infante-Amate J, Aguilera, E, Vila Traver J, Guzmán GI (2017) Decoupling food from land: the evolution of spanish agriculture from 1960 to 2010. Sustainability 9(12):23-48

Guzmán Casado G, Alonso Mielgo A (2009) Evaluación de la medida agroambiental Agricultura Ecológica en el periodo 2004-2006. In: González de Molina M (ed) El desarrollo de la agricultura ecológica en Andalucía (2004-2007): crónica de una experiencia agroecológica. Barcelona. Editorial Icaria, pp 67-80 
Infante-Amate J (2011) Los temporeros del olivar: una aproximación al estudio de las migraciones estacionales en el sur de España (siglos XVIII-XX). In: Revista de Demografía Histórica no 29, vol 2, pp 87-118

Infante-Amate J (2014) ¿Quién levantó los olivos? Historia de la especialización olivarera en el sur de España (s. XVIII-XX). Madrid. Ministerio de Agricultura, Alimentación y Medio Ambiente

Infante-Amate J, Soto D, Aguilera E, García Ruiz R, Guzmán G, Cid A, González de Molina M (2015), The spanish transition to industrial metabolism long-term material flow analysis (1860-2010) J Ind Ecol, 19(5):866-876. Available in: https://doi.org/10.1111/jiec.12261

INE (Instituto Nacional de Estadística) (1902) Censo de población de España 1900. Madrid

INE (Instituto Nacional de Estadística) (1913) Censo de población de España 1910. Madrid

INE (Instituto Nacional de Estadística) (1922) Censo de población de España 1920. Madrid

INE (Instituto Nacional de Estadística) (1932) Censo de población de España 190. Madrid

INE (Instituto Nacional de Estadística) (1943) Censo de población de España 1940. Madrid

INE (Instituto Nacional de Estadística) (1946) Anuario de estadística de 1944-1945. Madrid

INE (Instituto Nacional de Estadística) (1952) Censo de población de España 1950. Madrid

INE (Instituto Nacional de Estadística) (1958) Encuesta Presupuestos Familiares de 1958. Madrid

INE (Instituto Nacional de Estadística) (1974) Censo Agrario 1972. Madrid

INE (Instituto Nacional de Estadística) (1986) Censo Agrario 1982. Madrid

INE (Instituto Nacional de Estadística) (1992) Censo Agrario 1989. Madrid

INE (Instituto Nacional de Estadística) (1999) Censo Agrario 1999. Madrid

INE (Instituto Nacional de Estadística) (2008) Estadística e indicadores del agua. Madrid

INE (Instituto Nacional de Estadística) (2009) Censo Agrario 2009. Madrid

INE (Instituto Nacional de Estadística): Encuesta de Estructura de las Explotaciones Agrícolas. Madrid

INE (Instituto Nacional de Estadística): Encuesta de Población Activa. Madrid

INE (Instituto Nacional de Estadística): Series históricas de datos censales de España, (1900-2001), [web page]. Madrid. Available in: http://www.ine.es/censo2001/historia.htm

López Iglesias E (2006) El proceso de ajuste estructural en la agricultura española: caracterización general de las tendencias en las dos últimas décadas. Arnalte Alegre E (ed) Políticas agrarias y ajuste estructural en la agricultura española. Madrid. Ministerio de Agricultura, Pesca y Alimentación, pp 55-92

Maluquer de Motes J (2009a) Del caos al cosmos: una nueva serie enlazada del Producto Interior Bruto de España entre 1850 y 2000. Rev Econ Apl XVII(49):5-46

Maluquer de Motes J (2009b) Viajar a través del cosmos: la medida de la creación de la riqueza y la serie histórica del PIB. Rev Econ Apl XVII(51):25-54

Maluquer de Motes J (2013) La inflación en España: un índice de precios de consumo, (1830-2012). Madrid. Servicio de Publicaciones del Banco de España

Maluquer de Motes J (2016) España en la economía mundial: series largas para la economía española (1850-2015). Madrid. Instituto de estudios económicos

MAPA (Ministerio de Agricultura, Pesca y Alimentación) (2003) Encuesta sobre superficies y rendimientos de cultivos del año 2002. Memoria. Madrid

MAPAMA (Ministerio de Agricultura y Pesca, Alimentación y Medio Ambiente) (2017a) Agricultura Ecológica. Estadísticas 2016. Madrid. Available in: http://publicacionesoficiales.boe.es/

Marco I (2017) Dialogues on nature, class and gender: revisiting socio-ecological reproduction from past organic advanced to industrial agricultures (Sentmenat, Catalonia, 1860-1999). Barcelona. Universitat de Barcelona, Tesis doctoral inédita

Naredo JM (2004a) Reflexiones metodológicas en torno al debate sobre El pozo y el atraso de la agricultura española. Hist Agrar 33:151-164

Naredo JM (2004) La evolución de la agricultura en España (1940-2000). Granada. Universidad de Granada

Naredo JM, Sumpsi JM (1984) Caracterización de los modelos disciplinarios de trabajo agrario en las zonas de gran propiedad. Agricultura y Sociedad, no 33:45-86 
Prados de la Escosura L (2003) El progreso económico de España (1850-2000). Bilbao. Fundación BBVA

Prados de la Escosura L (2009) Del caos al cosmos: la serie del PIB de Maluquer de Motes. Revista de Economía Aplicada XVII(51):5-23

Prados de la Escosura L (2017) Spanish EconomicGrowth, 1850-2015; Suiza. Springer Nature Prees

Ramos García M, Guzmán GI, González de Molina M (2018) Dynamics of organic agriculture in Andalusia: moving towards conventionalisation? Agroecol Sustain Food Syst 42(3):328-359

Simpson J (1997) La agricultura española (1765-1965): la larga siesta. Alianza, Madrid

Soler Montiel M, Pérez Neira D, Molero Cortés J (2009) Cuentas económicas de la agricultura y ganadería ecológicas en Andalucía 2005. In: González de Molina M (ed) El desarrollo de la agricultura ecológica en Andalucía (2004-2007): crónica de una experiencia agroecológica. Barcelona. Editorial Icaria, pp 135-148

Villa I (2017) Transformaciones en el Metabolismo Agrario y su impacto socio-ecológico: Montefrío, 1750-1920. Universidad Pablo de Olavide de Sevilla, Tesis doctoral inédita, Sevilla

Open Access This chapter is distributed under the terms of the Creative Commons Attribution 4.0 International License (http://creativecommons.org/licenses/by/4.0/), which permits use, duplication, adaptation, distribution and reproduction in any medium or format, as long as you give appropriate credit to the original author(s) and the source, a link is provided to the Creative Commons license and any changes made are indicated.

The images or other third party material in this chapter are included in the work's Creative Commons license, unless indicated otherwise in the credit line; if such material is not included in the work's Creative Commons license and the respective action is not permitted by statutory regulation, users will need to obtain permission from the license holder to duplicate, adapt or reproduce the material. 